\title{
Can Residential Build to Rent provide a profitable low risk investment option?
}

\author{
N. Barnett \\ School of the built Environment and Architecture, London South Bank University, London

\section{Michael} \\ School of the Built Environment and Architecture, London South Bank University, London
}

\begin{abstract}
Purpose : Recently there has been a refocusing on the yields of investment assets. Accordingly, as risks to income yields rise, this research investigates how residential Build to Rent (BtR) may provide an effectively diversified portfolio. Emergence of this new investment sector requires a comparison between the rate of return of $(\mathrm{BtR})$ and other asset classes. We seek to ascertain how $\mathrm{BtR}$ can be used by investors to reduce risk and provide diversification benefits within a mixedasset portfolio.

Methodology:The research methodology adopted utilised secondary data produced by a reputable research organisation, coupled with personal interviews with major participants within the BtR sector.

Findings: Diversification of assets within an investment portfolio reduces the total risk and volatility of an investment portfolio based upon the Markowitz (1952) Modern Portfolio Theory (MPT) model. Analysis of BtR performance against other traditional asset classes including traditional investment property, proved BtR a valuable inclusion, reducing risk and providing valuable returns.

Discussion:Limited UK based research material on BtR as an investment option for institutions (and individuals), indicates its relatively short history as an investment option. Accordingly, some reliance was placed upon traditional private residential rental data. Despite this, the BtR investment asset in a mixed asset portfolio proved a source of long-term income with low volatility, rating favourably against other selected investment assets.
\end{abstract}

Keywords: Residential build, Low risk, Investment option

\section{Introduction}

Can residential BtR provide a reliable and profitable investment option as a major asset in an investment portfolio? Composition of an investment portfolio is crucial to its success; maximising returns while reducing risk. For decades, a ' $60-40$ ' portfolio composition of $60 \%$ equities and $40 \%$ bonds provided an attractive risk-return balance for investors (McMillan, 2019).

Bonds were historically a reliable long-term income choice and many equities flourished under globalisation. However, following the GFC of 2008/09, dominant monetary policy of extensive levels of quantitative easing has resulted in historically low interest rates in the UK. Recently, the U.S. Federal Reserve and European Central Bank took a dovish policy stance keeping rates and 
volatility levels low. Nonetheless, Q4 2018, the MSCI Global Equity index fell by $13.7 \%$ only to recover by $11.9 \%$ in Q1 2019 (MSCI, 2019). Consequently, the '60-40' model is no longer appropriate due to negative real returns on government bonds and has augmented speculative capital into alternative investments, including real estate, in mixed-asset portfolios. A more accurate portfolio ratio today is $40-40-20$ (IPD, 2014). Real estate offers a competitive risk-return trade-off and diversifies risk amongst further asset classes.

BtR asset class has little historical performance data or published research. Many returns initially provided to investors were based on forecasts with hard data unavailable and little apparent corroboration amongst academics on a suitable BtR weighting within a typical portfolio. Accordingly, a comprehensive analysis of UK BtR developments is needed to assess capital and rental value performance. With such data, a comparison of equities, bonds and cash equivalent returns is possible. Furthermore, no research exists regarding how BtR can reduce a total portfolio covariance. Whilst much is published on the correlation of mainstream classes, little exists on how BtR behaves. Contemporary and potential risks, and their impacts on diversification benefits of $B t R$, require investigation to assess suitability as a sustainable investment.

\section{Literature Review}

To ascertain the role BtR can play in expanding real estate allocations within a portfolio, relevant literature regarding real estate as an asset class was scrutinised to assess how particular assets demonstrate differing characteristics and offer diversification benefits to an investor.

Risk (or volatility) is traditionally measured by the standard deviation of returns. Two fundamental types of investment risk are: systematic and unsystematic. Systematic risk (measured by calculating the beta coefficient in the portfolio) impacts the entire market being affected by macroeconomic factors such as inflation, central bank policy changes and global economics. Conversely, unsystematic risk is industry or asset specific and can be minimised within a portfolio through diversification.

Diversification reduces total risk and volatility with the standard approach based on the Markowitz (1952) Modern Portfolio Theory (MPT) model. This empirical formula indicates how investors can maximise returns and reduce risk by selecting two or more assets of low covariance.

Recent inclusion of real estate within a portfolio has provided diversification benefits due to its low correlation with other assets (e.g. stocks, bonds, cash etc). However, the real estate industry comprises many different sectors including, but not limited to, commercial, industrial, logistics, retail and residential. One area which attracted significant attention from an institutional perspective is the UK residential private rented sector (PRS), which focuses solely on residential leasehold property. The PRS has grown rapidly and, at 4.5 million households, now represents $19 \%$ of the total market, up from 10\% in the 1980s and 1990s (English Housing Survey, 2018), driven by a supply/demand imbalance. UK households are expected to increase by an average 159,000 per year until 2041 (Office for National Statistics, 2018), yet private enterprise completions averaged only 109,765 per year since 2014 (Office for National Statistics, 2019). The corollary being upward pressure on house prices over the long run, with increased mortgage regulation through the Mortgage Market Review (MMR) of 2014 increasing buyer affordability constraints. As a result of this growth, the PRS now forms $47 \%$ of all UK institutional investment in real estate (IPF, 2018). This dominance is partially attributed to the relatively stable income stream compared with commercial real estate (CRE) being more directly affected by the business cycle.

This new BtR property investment sector could enhance long-term portfolio diversification. BtR delivers new purpose-built large-scale housing for the private rental sector with the average size of a completed scheme being 133 units, whilst schemes presently under construction average 240 
units (Savills, 2019). Over the past five years, BtR activity has received significant media coverage and gained momentum amongst many house builders and investors. Crucially, it also received support in Westminster, with changes in government policy designed to ameliorate the housing shortage. Additionally, BtR investors can benefit from capital growth, and arguably more importantly, rental income and its growth prospects. Subsequently, the volume of BtR developments grew to 140,090 in 2019; an increase of 13\% on 2018 (British Property Federation, 2019). However, despite its rapid growth, the BtR asset class is still relatively undeveloped and carries inherent risks.

\section{Real Estate within a portfolio}

Real estate allocation within a portfolio has been extensively researched using the Modern Portfolio Theory MPT model. Consequently, real estate is regarded an important diversifier and should ideally constitute $15 \%-40 \%$ of an efficiently diversified portfolio (Hartzell, Hekman, \& Miles, 1986; Hoesli, Lekander, \& Witkiewicz, 2004; Kallberg, Liu, \& Grieg, 1996). However, Cheng, Lin, Liu \& Zhang (2011) argue in reality, this figure is closer to 3\%-5\%. Under-allocation towards real estate can be largely explained by the "the fact that they ignore the non-identicallydistributed nature of real estate returns and apply MPT by only using unrealistic short-term real estate performance as inputs"(Cheng, et al., 2011). Alternatively, under-allocation could be due to the valuation-based rather than price-based returns compared with other asset classes. Consequently, MacGregor and Nanthakumaran (1992) question the reliability of MPT when including real estate and argue optimal theoretical allocations for property are higher than they should be. However, this research was completed 29 years ago and investor sentiment towards real estate has since improved drastically.

Real estate investment be direct or through an indirect investment vehicle - each offer a differing risk-return trade-off. Baum and Colley (2017) identified a significant level of capital, or higher risk relative to a market benchmark, would need to be employed when investing in direct real estate. Alternatively, indirect real estate investment requires lower capital but carries greater short-term risk (volatility) relative to a direct market benchmark (Baum and Colley,) Can Real Estate Investors Avoid Specific Risk,, due to increased liquidity of listed property investment vehicles and, to a lesser extent, Open Ended Investment Companies. Nonetheless, Mueller and Mueller (2003) and Byrne and Lee (1995) found real estate allocations can (and should) be increased, to improve efficient frontiers substantially. This is further supported by Hoesli, Lekander, and Witkiewicz (2004) who found inclusion of domestic real estate assets in mixedasset portfolios can reduce a portfolio's risk by $5-10 \%$ due to returns being poorly correlated with equities and bonds( Hoesli and Macgregor, 2000).

Whilst many investors utilise indirect investment vehicles (such as REITs), they have offered significantly reduced diversification benefits due to a close correlation with the share market (Heraney and Sriananthakumar, 2012). This view was developed further by Lee and Stephenson (2004) who identified that longer holding periods help alleviate this and real estate should be considered in a mixed-asset context.

Additionally, real estate has proven an effective hedge against inflation, which would encourage higher allocations to this asset class (Case and Wachter, 2011). Studies have shown "real estate returns are positively linked to anticipated inflation but not to inflation shocks" (Hoesli, et al., 2008 , p.2) so should be approached with some caution. This pattern of inflation behaviour is supported by Case and Wachter (2011) and Amenc, et al. (2009). Nonetheless, as mentioned previously, real estate behaves differently to equities, so is still a valuable diversifier from an inflation perspective. 
Despite these benefits, residential property has been found to be inherently inefficient with low transparency, liquidity and high transaction costs (Hwang, Cho and Shin, 2016). It must be noted however, this particular work focussed on the US real estate market and may not typify the UK. Nevertheless, both countries share similar economic attributes so these inefficiencies may still be applicable. Furthermore, the study reviews residential households rather than institutional investors who may take a longer-term view on liquidity where stability of income can be guaranteed. Nonetheless, UK BtR real estate inefficiencies are considered to assess the viability of including a substantial weighting within an investment portfolio.

\section{The Private Rental Sector (PRS)}

Research conducted by Miles and McCue (1982) and Eichholtz et al. (1995) found diversification by property type more effective than by geographic region. The PRS is a property type proven to offer diversification benefits for institutional investors (Mansfield, 2000). However, opportunities for market entry have been limited (Alakeson, 2012). As a result, UK PRS is largely unexplored and is isolated to niche areas, such as student accommodation (Thomas, 2017). Consequently, British institutions have invested a significantly smaller proportion of their portfolios in PRS than their European counterparts.

The general consensus amongst academics is significant barriers of entry prevented the PRS from becoming an attractive asset class (Coghill and Hardman, 2015; Mansfield, 2000; Pawson and Milligan, 2013. However, these studies didn't mention the PRS was a significant investment vehicle prior to World War One (WW1). Post WW1, one of the main deterrents was the PRS was associated with higher reputational risk, considering returns were reliant on capital appreciation, as opposed to rental yield (HM Treasury, 2010). This was due to introduction of the Increase of Rent and Mortgage Interest (War Restrictions) Act 1915 which controlled rents to stimulate the housing market. These controls were eventually abolished under the 1988 Housing Act, but continued to carry a stigma amongst investors in the years that followed. Today, England's rent control system is relatively non-existent, contributing toward a dramatic rise in capital entering the market (Moore, 2017). That said, new legislation relating to minimum lease terms on BtR developments may pose some liquidity issues. A recent report by Scanlon and Wilson (2017), examining BtR potential, stated 15 year covenants appear the industry norm which restricts the exit strategy for an investor and thus overall liquidity. Other disincentives for institutional investors included poor liquidity, high management costs, void period risk and unfavourable taxation (Mansfield, 2000). The lack of available large scale PRS stock was problematic for larger investors (IPF, 2018). Higher risks of PRS ultimately demanded higher returns which simply weren't on offer when compared with say commercial and retail (Baum, Commercial Real Estate Investment: A Strategic Approach, 2009).

Notably, research shows UK population growth, lifestyle change and house price affordability contribute towards a noticeable increase in the renting population; providing a ready market for BtR (Moore, 2017). London's rental population has grown 1.45\% since 2015, compared to Berlin at $0.31 \%$ and Amsterdam at $0.77 \%$ (United Nations, 2017). This growing popularity is a phenomenon known as 'Generation Rent' (McKee et al., 2017). The lack of quality private rented housing prompted the UK government to commission the Montague Review to examine potential actions to encourage growth in the sector (Montague , 2012). Most commentators(Hull and Cooke, 2012; Pawson and Wilcox, 2013; Wilson, Russell and Scanlon, 2017) acknowledge that, as a result of the Montague Review, government policy shifted to support growth of the PRS market. The government initially set up the BtR Fund to encourage investment into the sector. This was replaced in 2017 by the Home Building Fund (managed by Home and Communities Agency) supporting small and medium sized BtR developers. The revised National Planning 
Policy Framework published in July 2018 was updated in February 2019 and this legislation marks arrival of BtR into the planning mainstream encouraging further development and investment. Perhaps most significant, BtR schemes are exempt affordable housing requirements and can meet their contributions through 'Affordable Housing for Rent' (Wilson and Barton, 2019). This allows entire buildings to be retained under single ownership. Investors can therefore maintain full control over the asset, allowing simplified finance and management costs.

The effectiveness of the Montague Review is still in its infancy and changes to the planning system, in particular, are notoriously slow. In contrast however, an HM Treasury (2010) reported the recent institutional shift in appetite towards PRS investments can be apportioned to poor returns in Commercial Real Estate (CRE) and other sectors. Such low returns in CRE could be temporary, tied to lower interest rates and Brexit uncertainty, but a recent report by Savills (2019) suggest these returns follow a steady decline since the financial crisis in 2008 - as illustrated in Figure 1.

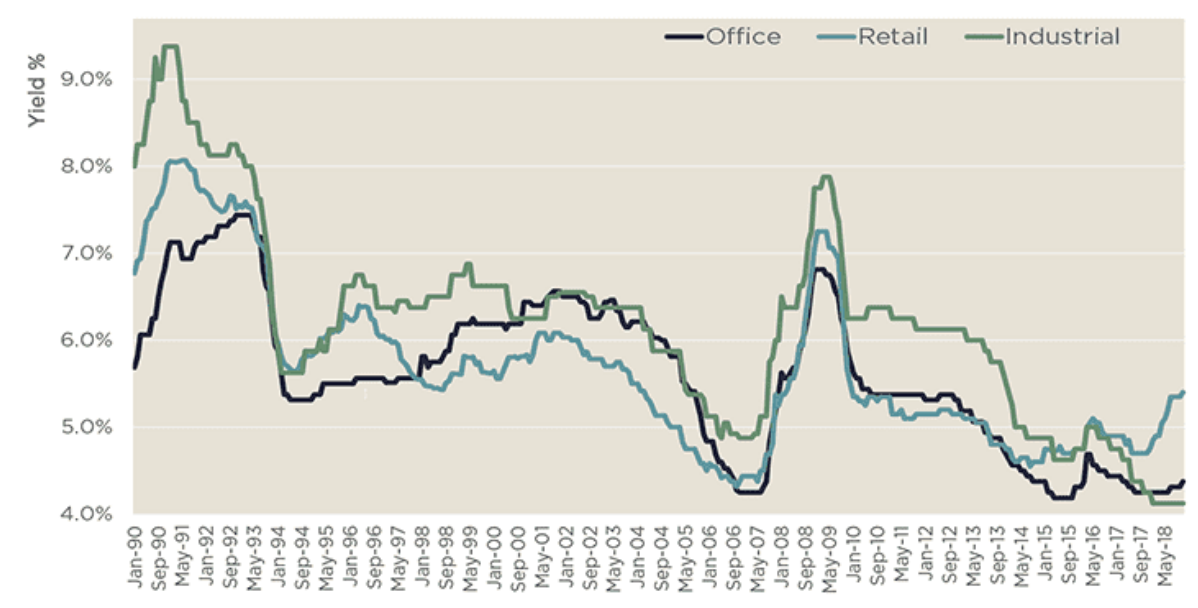

Figure 1 - Average prime yield across Office, Retail and Industrial (sourced from Savills, 2019)

PRS income yields are considered lower than many asset classes, but also notoriously more stable and reliable (Mueller and Mueller, 2003). Similarly, because of inelastic demand for rental housing, the PRS is more resilient to shocks in the economy, with the 2018 Annual Cyclical Scenario test showing UK residential property prices would fall $33 \%$ and UK commercial real estate prices fall $40 \%$ (Bank of England, 2018). This stability and consistency of BtR returns is suited to institutional investors (such as pension and insurance funds), where cash flow is more important than price appreciation to meet pension liabilities. Furthermore, Lin and Vandell (2007) found real estate risk decreases when holding periods increase due to high transaction costs involved. Notwithstanding, Collett, et al. (2003) identified holding periods are largely property dependent, as shopping centres, for example, typically have long holding periods due to liquidity issues and value added through extended management. Equally, the nature of PRS and BtR demands a long-term view, but it must be ascertained whether a longer holding period offers sufficient risk-adjusted returns compared with equities and bonds.

There is a lack of reliable UK long-term residential rental value series yet despite this, research (Hoesli et al 1997; Kuenzel and Bjornbak, 2008) shows UK rents have increased in line with inflation. Furthermore, the long run history for rental movements in USA, Germany, Netherlands and Ireland all show inflation matching characteristics (Mansley and Toplas, 2014) and investors generally regard the UK PRS a safe haven for capital. This is also linked to the fact residential rents have historically been much less volatile than house prices (Stephens and Williams, 2012). 
Of note also, the PRS has consistently produced healthier risk-adjusted returns with lower volatility than other real estate sectors over most time frames in the past 30 years (British Property Federation, 2013). However, it is possible the British Property Federation (BPF) projects an inflated view of the PRS considering their manifesto is to "promote the interests of all those with a stake in real estate in the UK" (British Property Federation, 2019, p. 1). This paper assesses whether stability and growth potential of the PRS can deliver higher risk-adjusted returns.

\section{Build to Rent}

With the above in mind, in theory, BtR should be considered an effective diversifier as it taps into the expanding PRS. BtR offers institutional investors potential for long-term income generation and theoretically low volatility compared to other asset classes, including equities and commercial property (Belson, 2015). Thomas (2017) argues this income generation could be jeopardised through increased regulation, a possibility mooted if a Labour government were to gain power. Ultimately, only time will tell the real returns achievable for BtR but this paper assesses the market today and identifies risks that may threaten its long term viability.

Investment managers, Invesco, found BtR schemes are now designed and constructed in a sustainable manner to allow a long life span with low risk of obsolescence (Invesco, 2016). This is further supported by international built asset consultancy firm EC Harris (2013), who calculated a 5-8\% discount to IPD data on overall management costs for new BtR properties. Nevertheless, higher quality developments come at greater expense and could result in maintenance issues in the long-term (Davies, 2017). Rugg and Rhodes (2018) found BtR developments include 'extras' such as gyms, dry cleaning, housekeeping services and a 24-hour concierge. This attempts to satisfy tenant demands and reduce turnover to minimise vacancies ensuring a consistent rental income. Colliers International (2018) research found professionally managed BtR schemes command a premium rent of between 9.4 and $9.9 \%$ compared with conventional Buy-to-Let properties but, these returns will vary across segments and locations. However, this premium rental proposition fills a market segment of more nomadic, career-focussed professionals able to buy but preferring flexibility that BtR can offer. This improved tenant covenant quality provides a lower risk and more attractive investment proposition. Thus, we seek to understand correlations with other asset classes and whether the higher build cost offers a sufficient riskreturn trade-off or investors.

Implementing the BtR model on a national scale could prove problematic. The most successful current PRS schemes are in urban locations, close to good transport links (Alakeson, 2012). Here, prospective tenants typically earn above average incomes and can afford the premium rents BtR developments tend to command. With this in mind, there is an inherent risk, from an investor's perspective, to identify appropriate locations where developments successfully meet the needs of a particular type of tenant. Therefore, it is important to evaluate the contribution that BtR across the UK can make to the investment portfolio and consider whether BtR is isolated to larger cities where rental demands and economies of scale work best, or whether the asset class can be scaled up geographically.

The UK BtR model is still in its infancy, with the first large-scale BtR scheme completed at East Village, Stratford in 2014. However, there are other markets which can be analysed to understand the potential of the BtR model, although these must be contextualised for the U.K. which has its own specific laws, culture, demographics and financial structure. Across Europe, the appetite for BtR (or Multi-family real estate as it is otherwise known) is already well established (Figure 2). 


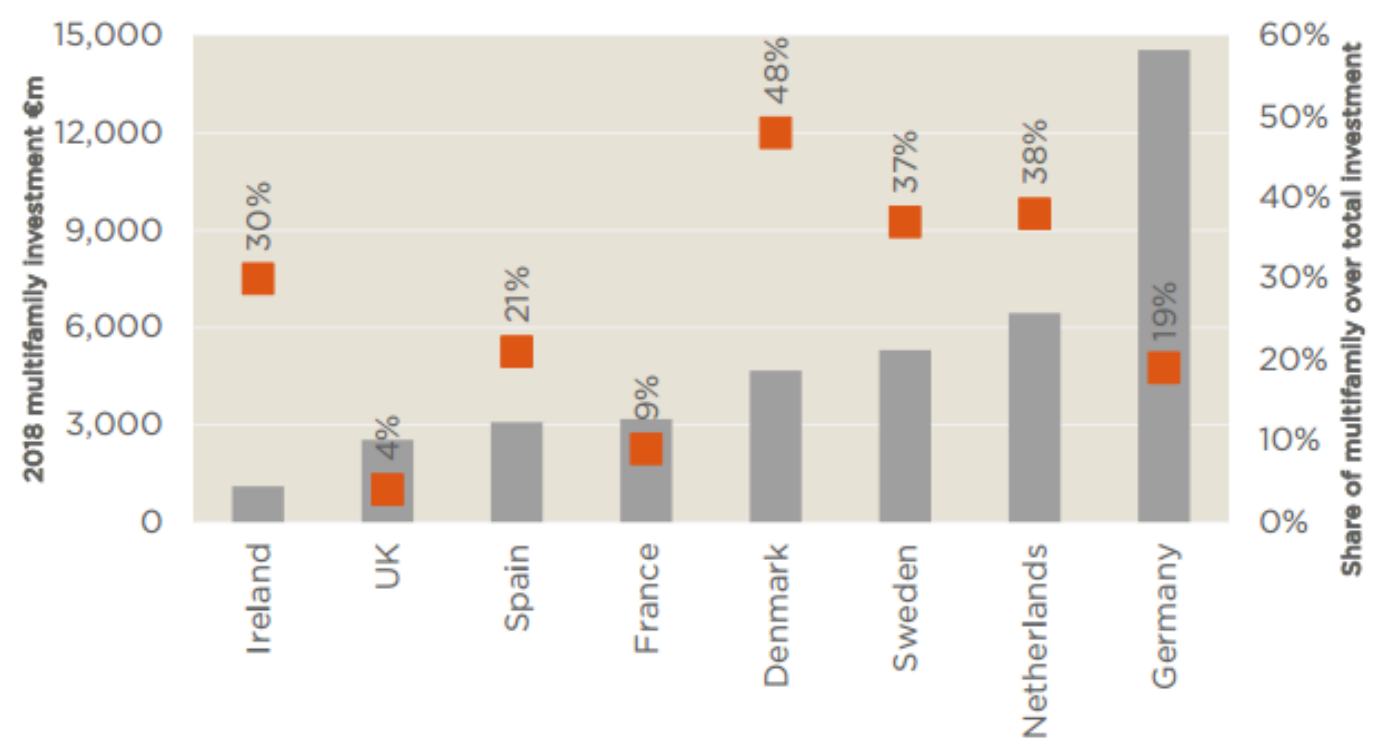

Figure 2 - European Multifamily investment 2018 (sourced from: Savills, 2019)

In the Netherlands, residential property is the dominant asset class, comprising over 50 per cent of institutional property portfolios (Montezuma, 2006). Capital is pouring into the Dutch PRS, with $€ 6.8$ billion invested by institutional, private and international investors in 2018, which was higher than commercial for the first time on record (Savills, 2019). Like the UK, a vast shortage of housing in the Netherlands ensures demand outweighs supply, forcing prices up $8.0 \%$ in 2018 (Savills, 2019). However, it should be recognised a much higher proportion of the Netherlands population rents compared to the UK - 30.6\% and 20\% respectively (Eurostat, 2019; Office for National Statistics, 2019). There are also significant rent controls in the Netherlands favouring a more stable proposition for renters and institutional investors. Accordingly, evidence suggests the UK BtR market can replicate the success of say the Netherlands, but perception of renting will have to improve and legislation change from central government may be required. This could possibly be overcome through effective marketing, selling the lifestyle of quality surroundings which the BtR sector offers. This would highlight social aspects of BtR and the ability to live amongst family-orientated, supportive and like-minded people as opposed to more transient tenants, which can be alienating and disruptive.

Similarly, the 'multi-family' living market is already a well-established market in the US. This sector anticipates 280,000 units to be delivered in 2019 (CBRE, 2019). In financial terms, the US multi-family market comprises 20 per cent of the PRS, having grown from $\$ 10 \mathrm{bn}$ in Q1, 2009 to just under \$80bn in Q3, 2016 (British Property Federation, 2017). Unsurprisingly, UK investors are starting to recognise $B t R$ has huge potential and can be embraced as an active diversification strategy.

Crucially though, inclusion of both residential AND commercial real estate is imperative to maximise diversification benefits. Commercial assets, such as office space, are traditionally favoured by investors due to longer lease structures providing more long-term security, and benefits from full repairing and insuring leases (FRI lease) are attractive. However, one study found "diversification benefits from direct investment in commercial real estate [were] reduced as the value of commercial property dropped along with falls in the value of A-REITS and the share market more generally" (Heaney and Sriananthakumar, 2012, p. 592).. Hence a mixed-asset portfolio is vital and there is an argument for increased allocation of PRS and BtR specifically. Savills (2018) reported a 478\% increase in the UK BtR development pipeline over the past five 
years. This meteoric rise is impressive but, as the sector matures, the risk premium will narrow and yields will compress.

The academic field has extensively explored both the real estate sector and PRS respectively. There can be little argument against inclusion of PRS assets within a mixed-asset portfolio. The merits are clear that, if managed correctly, PRS can offer significant diversification benefits for investors. From the above literature review it is evident there is need for further research on diversification benefits of $\mathrm{BtR}$ within the UK, which is still a relatively new asset class and rapidly evolving. Case studies from Germany and the Netherlands indicate the sector has massive potential, but the UK is a different proposition and needs examination to evaluate whether existing success of the PRS can be replicated with BtR developments. The recent update of the National Planning Policy Framework is likely to increase the appetite for investment, so it is important to provide guidance on returns available and effectiveness of this diversification.

\section{Research Questions / Hypothesis}

Our overall purpose is to establish whether inclusion of BtR (residential) in an investment portfolio that combines equities, gilts/bonds and CRE will reduce risk and enhance returns. To accomplish this, 25 BtR developments are studied to assess capital and rental growth, the rate of return of mainstream asset classes (equities, bonds and Real Estate Investment Trusts (REITs), is identified and the correlation behaviour and covariance between BtR and these mainstream asset classes to establish optimal allocations for BtR investments within a mixed portfolio. Any issues identified regarding BtR that could jeopardise its long-term viability as an asset class will be investigated and evaluated accordingly.

\section{Method}

\section{Research Model}

A mixed method research approach was adopted using secondary quantitative and primary qualitative research data to provide a deeper level of insight into the future potential of BtR. Studies show mixed methods research can produce more breadth, depth, and richness compared to either quantitative or qualitative methods alone (Schulze, 2003). The quantitative statistical analysis forms the foundation, with qualitative results providing supporting evidence.

\section{Quantitative research}

The relationship between returns of BtR developments and other mainstream asset classes was assessed using quantitative data enabling deductive reasoning to provide a clear and definitive answer. Research objectives can be tested and validated using a hard numerical data sample allowing generalisations to be made. This standardised approach allows further research to be conducted using the same methodology and/or calculations and is crucial for BtR research due to the limited number of completed schemes. Conversely, quantitative research sets out a hypothesis whereby historical performance data can be analysed. Although historical data may not be indicative of future results, it will provide an indication of how BtR behaved retrospectively versus other assets.

Analysis of secondary data collected by a third party, was scrutinised differently and compared to other variables. Considering BtR is still relatively immature, and long-term data limited, this provides important results for investors and academics.

Although still in the early stages of development, there are 30,357 completed BtR units across the UK (British Property Federation, 2019). More specifically, the total completed UK BtR schemes is 245 (Savills internal research). Each development was numbered and inserted into Microsoft Excel 'Random Function' to provide a sample of 25 individual developments. This included both 
operational and forward funded developments providing an overview of the market. This will eliminate bias that might otherwise arise from selecting individual developments.

Using annual total returns, risk-adjusted performance and portfolio diversification benefits of the twenty five UK BtR developments was assessed. Data obtained should provide a set of statistically robust results which either validates or invalidates the argument for including BtR as a portfolio asset. The data required is obtained from the MSCI database combined with Savills' internal market research (derived from developments Savills are directly involved with), which should cause minimal dilution of the results, is referenced and anonymised.

Additional benchmarks utilised are the FTSE EPRA/NAREIT UK series, FTSE 100 Share Index and ten-year UK government bonds.

\section{Quantitative Secondary data}

The secondary data obtained by a large market research company allowed access to a large 'cleaned' dataset, allowing a comprehensive analysis of BtR and an established global benchmark.

Fortunately there is little risk of time lag complications with secondary data as information dating back over 5 years simply does not exist.

Key information obtained from the quantitative data includes capital value of BtR developments, total rental values, net income yields for BtR compared with commercial investment performance, correlation analysis between BtR and other assets and a correlation analysis between BtR and property sub sectors.

Standard deviation has been used as the measure of asset performance volatility and provides the range in variation of returns from the average showing either a large spread of data or reveals returns are similar across the developments. A descriptive statistics package is used to determine volatility of asset returns and accordingly whether some asset volatility warrants the higher returns on offer.

Furthermore, the correlation between BtR with equities, bonds and other property sectors will determine whether its inclusion in a portfolio will reduce overall volatility.

Finally, the Sharpe Ratio will be calculated to understand the risk-adjusted asset within the context of a financial portfolio. The Sharpe Ratio measures the return above the risk free rate after adjusting for volatility (risk) and is calculated as follows:

\section{(Average Asset Return - Risk Free Rate)}

\section{Average Standard Deviation}

This ratio allows a comparison of multiple investments and dissipates volatility. According to the Sharpe ratio, an asset expressing a higher standard deviation is not necessarily unattractive, provided it is accompanied by a proportionally higher return.

Due to immaturity of the BtR sector, residential data is used to give a more accurate long-term representation of behaviour. The correlation coefficient is calculated using the Analysis Toolpak add-in in Microsoft Excel.

\section{Qualitative research}

Empirical data is crucial in understanding the financial merits of BtR. However, this research is partially exploratory in assessing a relatively immature asset class. Accordingly, qualitative research was used to gauge the experiences and perspectives of professionals in the field about growth potential of BtR. 
Qualitative research aligns with the interpretivist paradigm being an inductive process which "reflect[s] some sort of individual phenomenological perspective" (Newman, Benz, \& Ridenour, 1999, p. 2). Inductive research involves observing patterns to establish outcomes where a preestablished theory doesn't exist. Although more subjective, this may provide insight into more philosophical issues surrounding $B t R$, and provide further understanding of potential future risks of $\mathrm{BtR}$ and potential optimal asset allocations.

\section{Population and Sampling}

Interviewees were selected from five disciplines, each involved within development or management of BtR. Five separate interviewees is a reasonable number to ensure high quality results and achieves a diversity expected within the research sample satisfying epistemic community requirements. Five semi-structured interviews (SSIs) surveyed participants' perspectives regarding their experience with BtR. Open-ended questions were asked in the same order and respondents answered in their own time.

The selected interviewees comprised:

Respondent 1) Managing Director of a development consultancy practice directly involved in BtR developments across the South East of England. Over 20 years' experience in the architecture and planning sector.

Respondent 2) Head of Investment for one of the UK's leading housing associations with a growing involvement in the BtR Sector. Over 10 years' experience in real estate investment.

Respondent 3) Director for a leading finance brokerage involved with forward funding BtR developments across the UK. Over 20 years' experience in property finance

Respondent 4) Director for a global real estate consultancy firm, working within a department which specialises in BtR investments.

Respondent 5) CEO of an independent asset management firm with BtR developments included within their portfolio. Over 10 years' experience in asset management.

\section{Interview Questions}

Five questions were asked:

1. What do you envisage being the main risks of investing in BtR?

2. What allocation do you think is appropriate for Build to Rent within a portfolio?

3. Can BtR, as an investment, be effectively scaled up considering the existing concentration around urban centres?

4. How do you view BtR compared with traditional commercial real estate? Is it a substitute or a complimentary investment?

5. The previous five years has seen BtR develop considerably. How do you foresee this asset class developing further over the next five years?

Interview data was analysed to provide a descriptive summary of participants' perspectives. and interviews transcribed from audio to text. 


\section{Data Analysis}

The interviewee sample size is relatively small, yet data obtained was detailed and informative. Results were interpreted to understand participants' perceptions of BtR. This methodology seeks to "understand, describe, and interpret human behaviour and the meaning individuals make of their experience" (Kivunja \& Kuyini, 2017, p. 37). Rigorous and relevant thematic content analysis of the results should provide insight, knowledge and experience of the respondents. Thematic content analysis identifying patterns or themes establishes important or interesting aspects, used to increase understanding of professional sentiment towards BtR. The process followed Braun and Clarke's (2006) six-phase framework for thematic analysis:

Step 1 - Familiarise yourself with the data

Step 2- Generate codes

Step 3- Identify themes

Step 4- Review themes

Step 5- Define themes

Step 6- Write up conclusion

This framework helped ensure material was comprehensively processed enabling large amounts of text to be streamlined and analysed to illustrate and the primary objectives whilst minimising cognitive bias.

\section{BtR Sampling}

Random sampling removes any selection bias as proven by previous studies(Cuddeback et al., 2004; Keeble et al., 2015). Our sample size may be relatively small ( $9.8 \%$ of all developments) but it allowed detailed information to be obtained for each building, which produced interesting results.

\section{Returns of BtR}

Lack of a long time series data is frustrating, but expected given the infancy of this asset class. Sufficient information to accurately compare BtR developments over a 5-year period was not available. Savills, (the main source of information for the BtR data) recognised the need for further data, which should emerge over the next 5-10 years BtR, like student accommodation, may be recognised as a stand-alone asset class. Nonetheless, Savills were involved in the majority of BtR transactions in recent years, and this valuable data has been scrutinised.

As previously discussed, management costs for BtR schemes are typically higher than a traditional residential development, due to a focus on providing high quality customer service and premium facilities. We found most developers and investors are factoring in a $24-26 \%$ running cost for their developments. Some developers established affiliated management companies to encourage economies of scale and lower overall costs. These impact the Net Initial Yield (NIY) of schemes. Internalisation of property management by developers is a principle addressed in the wider literature, namely by Thomas (2017), and is likely to gain traction in coming years.

Taking all costs into account, the sample mean NIY was 3.85\% with median NIY of 3.83\%. The majority of these properties are focussed around major centres, with $80 \%$ in Greater London. Investing outside of major urban centres is considered riskier by some due to reduced job security and more volatile economic growth (Huston, Rahimzad, \& Parsa, 2015). Consequently secondary 
locations command much higher Net Initial Yields. These 'second-tier' towns and cities command up to a $32 \%$ premium NIY versus central London developments. Growth in secondary locations is important for future BtR as there is a huge market to explore (Cardoso and Meijers, 2017). These regional hubs make a massive contribution to the wider national economy and integrating a mix of suitable tenures could be valuable to developers and investors. Figure 3 demarcates the disparity between yields across the country. As the sector develops and investors take more confidence from other urban centres, yields may compress. This links with increased competition for and supply constraints of land. Furthermore, an influx of completed units may lower average rents, at least in the short-term.

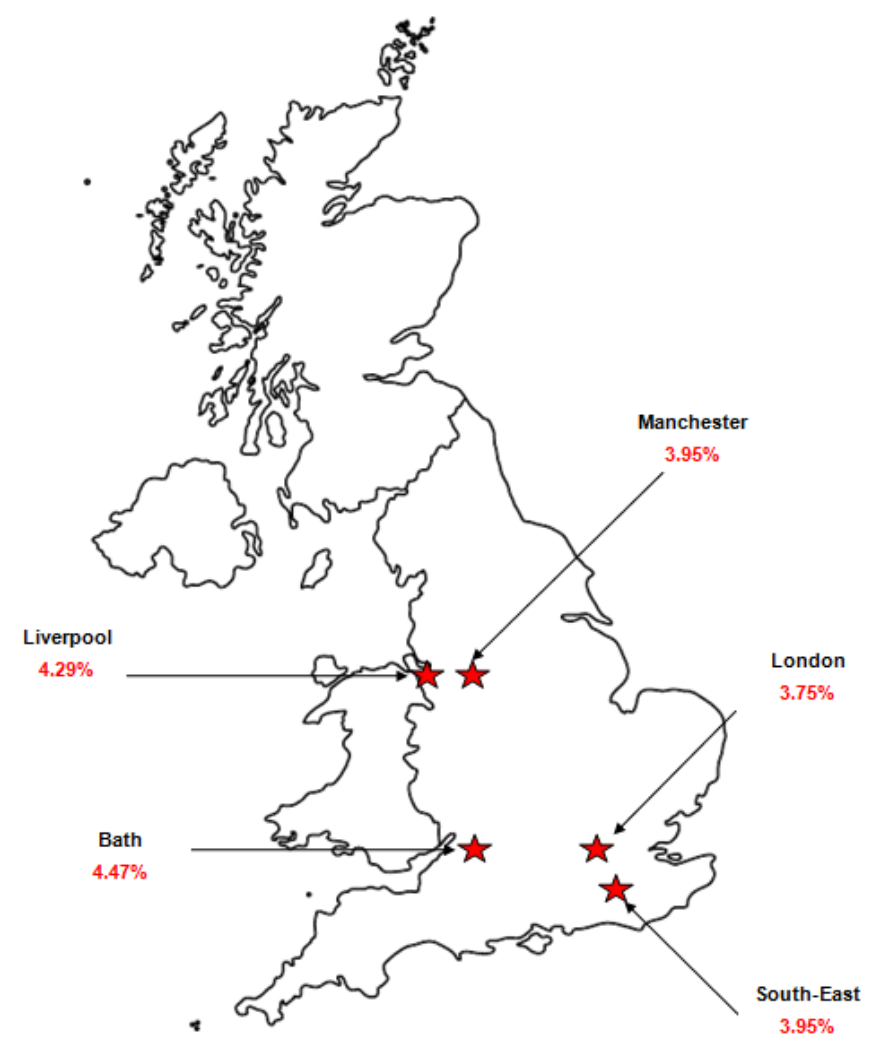

Figure 3 - Net yields for Build to Rent developments across the UK Source: Authors' compilation/analysis

Due to stability of income and long-term growth potential BtR appears to offer, investors have flocked to invest. The longer holding period and investment strategy required for BtR coupled with a more illiquid market investment, explained the comparatively low NIY of the sample studied. BtR NIY is lower than other major property sectors (except West End Office) (see Figure 4). This is not necessarily a problem for an institutional investor, as many view it a complimentary or general diversifier to overall real estate exposure. 


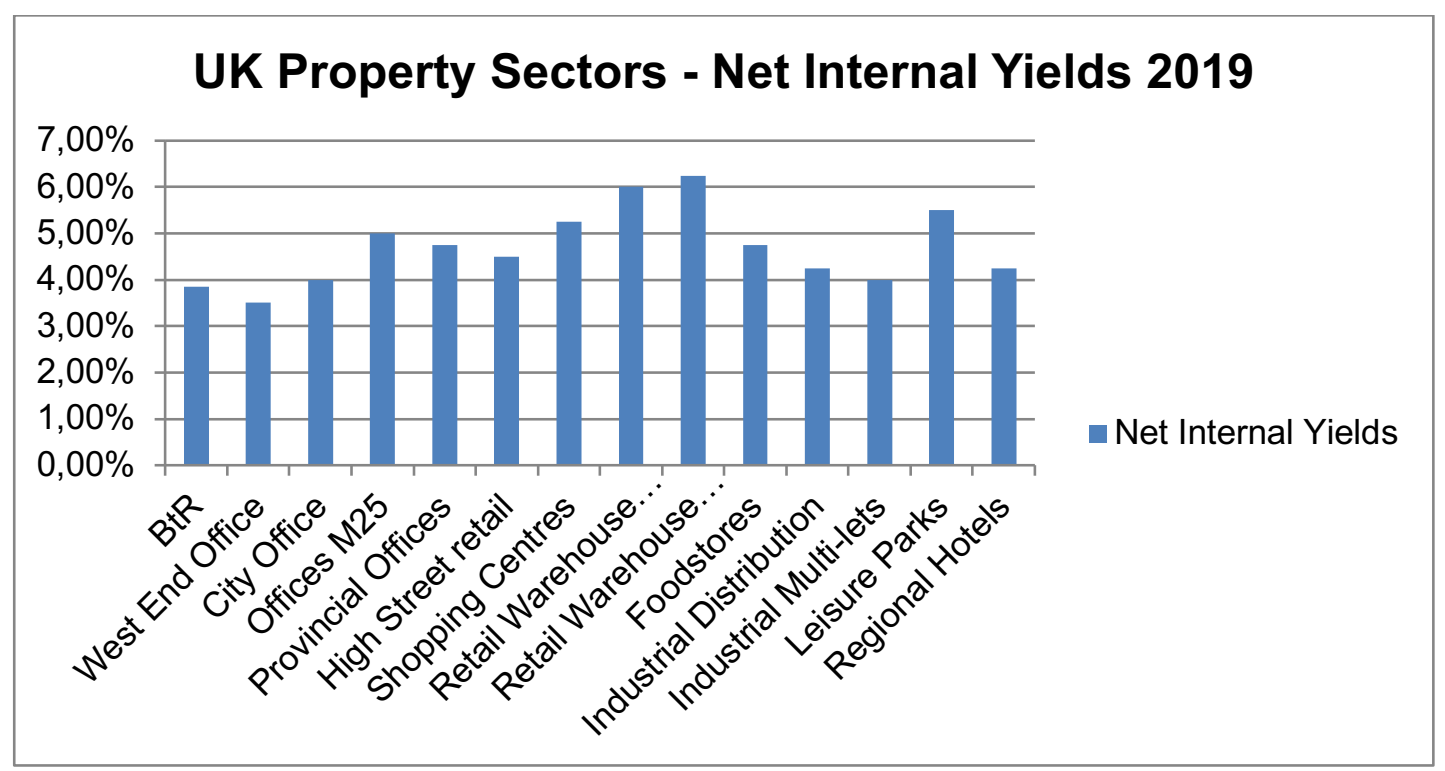

Figure 4 - UK Property Sectors- Net Internal Yields

Source: Authors' compilation/analysis and Savills, 2019

Mainstream asset class returns

A growing interest in investment returns and volatility followed the GFC. Since the Brexit referendum in June 2016, investment markets experienced varying levels of volatility. The logistics real estate sector thrived in recent years, being top property performer over the past 5 years, while retail suffered due to e-commerce. Over a 10-year period however, returns are generally more similar except for retail and 10-year Gilts.

An investor will, ceteris paribus, select investments with lower volatility. Hata! Başvuru kaynağı bulunamad1. outlines standard deviations of each property sub-sector and alternative assets. Over the past 5-years, residential proved the second least volatile asset (3.01) behind 10-year Gilt (0.37).

Table 1 - Standard deviation values for individual asset classes

\begin{tabular}{|l|l|}
\hline Asset class & 5-year standard deviation \\
\hline All & 5.76 \\
\hline Retail & 6.23 \\
\hline Office & 8.62 \\
\hline Industrial & 5.83 \\
\hline Hotel & 3.36 \\
\hline Residential & 3.01 \\
\hline FTSE 100 Index & 11.09 \\
\hline FTSE EPRA Nareit UK & 14.69 \\
\hline UK 10-year Gilt & 0.37 \\
\hline
\end{tabular}

Source: Authors' compilation/analysis (Bank of England, 2019; MSCI, 2019; Investing.com, 2019; Investing.com, 2019)

BtR provides long run stable returns to a portfolio. Nonetheless, more volatile investments listed above can still form part of a balanced portfolio. 


\section{Risks of BtR}

Risk-adjusted returns assessed using the Sharpe ratio assessed risk-adjusted performance of UK residential with other direct property sectors over the period December 2014 - December 2018. The risk-adjusted returns (via Sharpe ratio) saw Hotel as best-performed property sector (3.24), ahead of Industrial (2.65) and other property sectors. Residential performed relatively well with a Sharpe ratio of 2.18, generating a level well in excess of the Risk Free Rate. This supports studies by Rugg and Rhodes (2018) who found residential investment performed consistently well in recent years, outstripping other asset classes. Although no specific figures exist for BtR, the residential data is still applicable and demonstrates the suitability of including BtR within a portfolio (Scanlon, Whitehead, Blanc, \& Moreno-Tabarez, 2017). Additionally, low vacancy rates compared to traditional commercial investments, further reduce BtR risks (Figure 5).

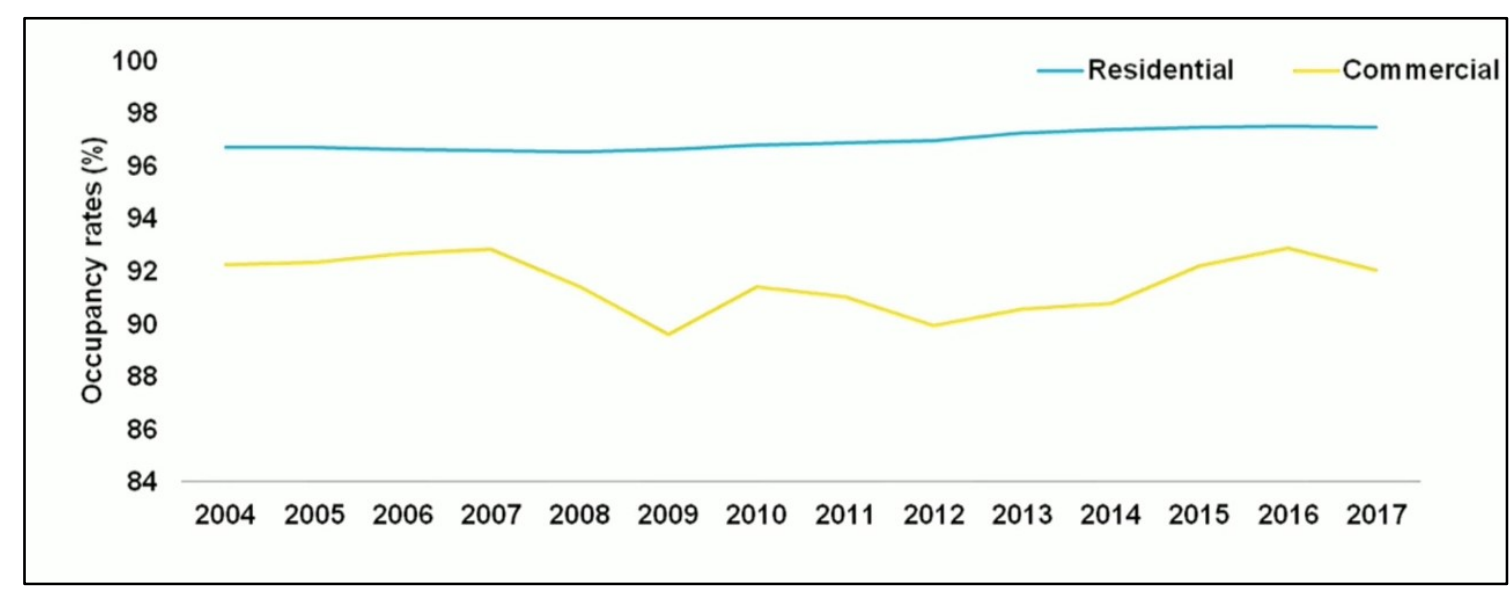

Figure 5 - Occupancy rates of UK Commercial and Residential property

Source: $L \& G, 2019$ Hata! Başvuru kaynağı bulunamadı. represents the risk-adjusted performance of UK residential property in mixed-asset portfolio context. This illustrates residential returns as amongst the highest available $(8.00 \%)$ ahead of both the FTSE $100(4.36 \%)$ and EPRA Nareit (4.21\%). Similarly, risks associated with residential property were low $(3.01 \%)$ particularly when compared with EPRA Nareit (14.69\%). Resulting Sharpe ratios show residential delivering the best risk-adjusted performance. Considering BtR exhibits the same characteristics as residential property (and will only carry further stability due to longer tenancy agreements and possibly economies of scale), this is a profound argument for inclusion within a portfolio.

Table 2 - Risk-adjusted performance analysis of residential property vs. other major assets: 2008-2018

\begin{tabular}{|l|r|r|r|r|r|}
\hline & $\begin{array}{r}\text { 5 year } \\
\text { average }\end{array}$ & $\begin{array}{r}\text { Standard } \\
\text { deviation }\end{array}$ & $\begin{array}{r}\text { Risk Free } \\
\text { Rate }\end{array}$ & $\begin{array}{r}\text { Sharpe } \\
\text { Ratio }\end{array}$ & Rating \\
\hline All & 9.90 & 5.76 & 1.445 & 1.47 & 2.00 \\
\hline Residential & 8.00 & 3.01 & 1.445 & 2.18 & 1.00 \\
\hline FTSE 100 Index & 4.36 & 11.09 & 1.445 & 0.26 & 3.00 \\
\hline FTSE EPRA Nareit UK & 4.21 & 14.69 & 1.445 & 0.19 & 5.00 \\
\hline $\begin{array}{l}\text { UK 10-year Gilt } \\
\text { *Risk Free Rate = 10-yr Gilt } \\
\text { as of 31/12/2018 }\end{array}$ & 1.62 & 0.37 & 1.445 & 0.47 & 4.00 \\
\hline
\end{tabular}

Source: Authors' compilation/analysis 
Property asset class characteristics and performance can change over time. Diversification benefits of varied property types are indicated within Table 3.

Table 3 - Correlations indicating diversification benefits of UK residential and other UK property sectors: $2009-2018$

\begin{tabular}{|l|r|r|r|r|r|r|}
\hline & All property & \multicolumn{1}{|c|}{ Retail } & Office & Industrial & Hotel & Residential \\
\hline All Property & 1.00 & & & & & \\
\hline Retail & 0.90 & 1.00 & & & & \\
\hline Office & 0.97 & 0.82 & 1.00 & & & \\
\hline Industrial & 0.70 & 0.36 & 0.68 & 1.00 & & \\
\hline Hotel & 0.90 & 0.71 & 0.87 & 0.82 & 1.00 & \\
\hline Residential & 0.56 & 0.72 & 0.58 & -0.01 & 0.30 & 1.00 \\
\hline
\end{tabular}

Source: Authors' compilation/analysis

Characteristics of different asset classes are well-known, although constantly changing. The property portfolio diversification benefits of UK residential are indicated in Tables 3 and 4 by the Pearson 'product-moment correlation coefficient', measured on a standard scale ranging between -1.0 and +1.0 .

Table 3 demonstrates residential properties, and therefore BtR, are not significantly correlated with alternative property sectors, ( 0.56 with all property, and the highest correlation of 0.72 with retail which is undergoing structural disruption due to ecommerce), reflecting diversification benefits of BtR. This is particularly relevant with correlations between retail, office, industrial, hotel and total property $(\mathrm{r}=0.90-0.70)$, reflecting their lack of diversification benefits.

Additionally, Hata! Başvuru kaynağı bulunamadı. illustrates correlations with other UK assets. The correlation between residential property with equities (0.20), REITs (0.37) and UK Gilts (0.10) all remain relatively low. Fundamentally, residential inclusion provides a key diversifier in an investment portfolio. Further analysis highlights specific BtR benefits with long-term returns in particular proving attractive.

Table 4 - Diversification benefits of UK residential and other UK assets: 2009-2018

\begin{tabular}{|c|c|c|c|c|c|}
\hline & Residential & $\begin{array}{l}\text { FTSE } 100 \\
\text { Index }\end{array}$ & $\begin{array}{c}\text { FTSE EPRA } \\
\text { Nareit UK }\end{array}$ & $\begin{array}{c}\text { UK 10-year } \\
\text { Gilt }\end{array}$ & $\begin{array}{c}\text { All } \\
\text { Property }\end{array}$ \\
\hline Residential & 1.00 & & & & \\
\hline $\begin{array}{l}\text { FTSE } 100 \\
\text { Index }\end{array}$ & 0.19 & 1.00 & & & \\
\hline $\begin{array}{l}\text { FTSE EPRA } \\
\text { Nareit UK }\end{array}$ & 0.59 & 0.37 & 1.00 & & \\
\hline $\begin{array}{l}\text { UK 10-year } \\
\text { Gilt }\end{array}$ & 0.75 & 0.48 & 0.28 & 1.00 & \\
\hline All Property & 0.56 & -0.28 & 0.24 & 0.18 & 1.00 \\
\hline
\end{tabular}

Source: Authors' compilation/analysis

Optimal asset allocation

Composition of a portfolio is largely linked to the profile of the investor. Key factors to consider are the investor's goals, age and risk tolerance but with portfolio asset selection, the key is to minimise overall variance whilst maximising returns. A short-sale constraint has been used in our calculations, which means all asset weighting must be greater than or equal to zero. 
The standard deviation of all nine assets was compared with total expected return when weightings are adjusted to different levels. This relies on the Covariance Matrix of all assets.

Table 5 - Covariance matrix of assets

\begin{tabular}{|c|c|c|c|c|c|c|c|c|c|c|}
\hline $\begin{array}{l}\text { Portfolio } \\
\text { Weights }\end{array}$ & & $11.11 \%$ & $11.11 \%$ & $11.11 \%$ & $11.11 \%$ & $11.11 \%$ & $11.11 \%$ & $11.11 \%$ & $11.11 \%$ & $11.11 \%$ \\
\hline & & All & Retail & Office & Industrial & Hotel & Residential & $\begin{array}{c}\text { FTSE } \\
100 \\
\text { Index }\end{array}$ & $\begin{array}{c}\text { FTSE } \\
\text { EPRA } \\
\text { Nareit } \\
\text { UK }\end{array}$ & $\begin{array}{l}\text { UK 10- } \\
\text { year Gitt }\end{array}$ \\
\hline $11.11 \%$ & All & 0.0024 & 0.0023 & 0.0032 & 0.0022 & 0.0018 & 0.0007 & -0.0015 & 0.0017 & 0.0001 \\
\hline $11.11 \%$ & Retail & 0.0023 & 0.0027 & 0.0029 & 0.0012 & 0.0015 & 0.0009 & 0.0001 & 0.0024 & 0.0002 \\
\hline $11.11 \%$ & Office & 0.0032 & 0.0029 & 0.0047 & 0.0030 & 0.0025 & 0.0010 & -0.0030 & 0.0028 & 0.0001 \\
\hline $11.11 \%$ & Industrial & 0.0022 & 0.0012 & 0.0030 & 0.0043 & 0.0023 & 0.0000 & -0.0034 & 0.0001 & -0.0002 \\
\hline $11.11 \%$ & Hotel & 0.0018 & 0.0015 & 0.0025 & 0.0023 & 0.0018 & 0.0003 & -0.0013 & 0.0005 & 0.0000 \\
\hline $11.11 \%$ & Residential & 0.0007 & 0.0009 & 0.0010 & 0.0000 & 0.0003 & 0.0006 & 0.0005 & 0.0021 & 0.0001 \\
\hline $11.11 \%$ & $\begin{array}{l}\text { FTSE } 100 \\
\text { Index }\end{array}$ & -0.0015 & 0.0001 & -0.0030 & -0.0034 & -0.0013 & 0.0005 & 0.0117 & 0.0055 & 0.0004 \\
\hline $11.11 \%$ & $\begin{array}{l}\text { FTSEEPRA } \\
\text { Nareit UK }\end{array}$ & 0.0017 & 0.0024 & 0.0028 & 0.0001 & 0.0005 & 0.0021 & 0.0055 & 0.0197 & 0.0003 \\
\hline $11.11 \%$ & $\begin{array}{l}\text { UK 10-year } \\
\text { Gilt }\end{array}$ & 0.0001 & 0.0002 & 0.0001 & -0.0002 & 0.0000 & 0.0001 & 0.0004 & 0.0003 & 0.0001 \\
\hline $\begin{array}{l}100.00 \\
\%\end{array}$ & & 0.0002 & 0.0002 & 0.0002 & 0.0001 & 0.0001 & 0.0001 & 0.0001 & 0.0004 & 0.0000 \\
\hline
\end{tabular}

Source - Author compiled

The Covariance Matrix allows a comparison of the relationships between mean values of the different groups. Results of the asset allocation calculations are outlined in Table 5.

Table 6 - Efficient Frontier for 9 assets within a mixed portfolio

\begin{tabular}{|c|c|c|c|c|c|c|c|c|c|c|c|}
\hline & & $\begin{array}{c}\text { Min } \\
\text { Varia } \\
\text { nce }\end{array}$ & & & & & $\begin{array}{l}\text { Optim } \\
\text { um }\end{array}$ & & & & \\
\hline Mean & & $2.75 \%$ & $\begin{array}{l}3.5 \\
0 \%\end{array}$ & $\begin{array}{l}4.5 \\
0 \%\end{array}$ & $\begin{array}{l}5.5 \\
0 \%\end{array}$ & $\begin{array}{l}6.5 \\
0 \%\end{array}$ & $7.50 \%$ & $\begin{array}{l}8.5 \\
0 \%\end{array}$ & $\begin{array}{l}9.9 \\
7 \%\end{array}$ & $\begin{array}{l}10 . \\
50 \\
\%\end{array}$ & $\begin{array}{l}11 . \\
50 \\
\%\end{array}$ \\
\hline Standard Deviation & 0 & $0.71 \%$ & $\begin{array}{l}0.8 \\
2 \% \\
\end{array}$ & $\begin{array}{l}1.0 \\
2 \%\end{array}$ & $\begin{array}{l}1.2 \\
3 \% \\
\end{array}$ & $\begin{array}{l}1.4 \\
6 \%\end{array}$ & $1.69 \%$ & $\begin{array}{l}1.9 \\
2 \% \\
\end{array}$ & $\begin{array}{l}2.2 \\
6 \%\end{array}$ & $\begin{array}{l}2.7 \\
1 \% \\
\end{array}$ & $\begin{array}{l}4.4 \\
8 \%\end{array}$ \\
\hline Sharpe Ratio & & 1.84 & $\begin{array}{c}2.5 \\
1 \\
\end{array}$ & $\begin{array}{c}3.0 \\
0 \\
\end{array}$ & $\begin{array}{c}3.2 \\
9 \\
\end{array}$ & $\begin{array}{c}3.4 \\
7 \\
\end{array}$ & 3.59 & $\begin{array}{c}3.6 \\
8 \\
\end{array}$ & $\begin{array}{c}3.7 \\
7 \\
\end{array}$ & $\begin{array}{c}3.3 \\
4 \\
\end{array}$ & $\begin{array}{c}2.2 \\
4 \\
\end{array}$ \\
\hline All & & $0.00 \%$ & $\begin{array}{l}0.0 \\
0 \% \\
\end{array}$ & $\begin{array}{l}0.0 \\
0 \% \\
\end{array}$ & $\begin{array}{l}0.0 \\
0 \% \\
\end{array}$ & $\begin{array}{l}0.0 \\
0 \% \\
\end{array}$ & $0.00 \%$ & $\begin{array}{l}0.0 \\
0 \%\end{array}$ & $\begin{array}{l}0.0 \\
0 \%\end{array}$ & $\begin{array}{l}0.0 \\
0 \%\end{array}$ & $\begin{array}{l}0.0 \\
0 \%\end{array}$ \\
\hline Retail & & $0.00 \%$ & $\begin{array}{l}0.0 \\
0 \% \\
\end{array}$ & $\begin{array}{l}0.0 \\
0 \% \\
\end{array}$ & $\begin{array}{l}0.0 \\
0 \% \\
\end{array}$ & $\begin{array}{l}0.0 \\
0 \%\end{array}$ & $0.00 \%$ & $\begin{array}{l}0.0 \\
0 \% \\
\end{array}$ & $\begin{array}{l}0.0 \\
0 \% \\
\end{array}$ & $\begin{array}{l}0.0 \\
0 \% \\
\end{array}$ & $\begin{array}{l}0.0 \\
0 \% \\
\end{array}$ \\
\hline Office & & $0.00 \%$ & $\begin{array}{l}0.0 \\
0 \% \\
\end{array}$ & $\begin{array}{l}0.0 \\
0 \% \\
\end{array}$ & $\begin{array}{l}0.0 \\
0 \% \\
\end{array}$ & $\begin{array}{l}0.0 \\
0 \% \\
\end{array}$ & $0.00 \%$ & $\begin{array}{l}0.0 \\
0 \% \\
\end{array}$ & $\begin{array}{l}0.0 \\
0 \% \\
\end{array}$ & $\begin{array}{l}0.0 \\
0 \% \\
\end{array}$ & $\begin{array}{l}0.0 \\
0 \% \\
\end{array}$ \\
\hline Industrial & & $5.37 \%$ & $\begin{array}{l}9.0 \\
5 \%\end{array}$ & $\begin{array}{l}10 . \\
81 \\
\% \\
\end{array}$ & $\begin{array}{l}12 . \\
56 \\
\% \\
\end{array}$ & $\begin{array}{l}14 . \\
31 \\
\%\end{array}$ & $16.06 \%$ & $\begin{array}{l}17 . \\
81 \\
\% \\
\end{array}$ & $\begin{array}{l}20 . \\
82 \\
\% \\
\end{array}$ & $\begin{array}{l}40 . \\
47 \\
\% \\
\end{array}$ & $\begin{array}{l}77 . \\
59 \\
\% \\
\end{array}$ \\
\hline Hotel & & $0.00 \%$ & $\begin{array}{l}0.0 \\
0 \% \\
\end{array}$ & $\begin{array}{l}0.0 \\
0 \%\end{array}$ & $\begin{array}{l}0.0 \\
0 \% \\
\end{array}$ & $\begin{array}{l}0.0 \\
0 \%\end{array}$ & $0.00 \%$ & $\begin{array}{l}0.0 \\
0 \% \\
\end{array}$ & $\begin{array}{l}0.0 \\
0 \%\end{array}$ & $\begin{array}{l}0.0 \\
0 \% \\
\end{array}$ & $\begin{array}{l}0.0 \\
0 \%\end{array}$ \\
\hline Residential & & $0.00 \%$ & $\begin{array}{l}4.7 \\
1 \%\end{array}$ & $\begin{array}{l}15 . \\
31 \\
\%\end{array}$ & $\begin{array}{l}25 . \\
90 \\
\%\end{array}$ & $\begin{array}{c}36 . \\
50 \\
\%\end{array}$ & $47.09 \%$ & $\begin{array}{l}57 . \\
69 \\
\%\end{array}$ & $\begin{array}{c}72 . \\
60 \\
\%\end{array}$ & $\begin{array}{l}48 . \\
93 \\
\%\end{array}$ & $\begin{array}{l}4.2 \\
0 \%\end{array}$ \\
\hline
\end{tabular}




\begin{tabular}{|c|c|c|c|c|c|c|c|c|c|c|c|}
\hline FTSE 100 Index & & $0.00 \%$ & $\begin{array}{l}0.6 \\
5 \%\end{array}$ & $\begin{array}{l}1.5 \\
5 \%\end{array}$ & $\begin{array}{l}2.4 \\
5 \%\end{array}$ & $\begin{array}{l}3.3 \\
6 \%\end{array}$ & $4.26 \%$ & $\begin{array}{l}5.1 \\
7 \%\end{array}$ & $\begin{array}{l}6.5 \\
8 \%\end{array}$ & $\begin{array}{l}10 . \\
61 \\
\%\end{array}$ & $\begin{array}{l}18 . \\
21 \\
\%\end{array}$ \\
\hline $\begin{array}{c}\text { FTSE EPRA Nareit } \\
\text { UK }\end{array}$ & & $0.00 \%$ & $\begin{array}{l}0.0 \\
0 \%\end{array}$ & $\begin{array}{l}0.0 \\
0 \%\end{array}$ & $\begin{array}{l}0.0 \\
0 \%\end{array}$ & $\begin{array}{l}0.0 \\
0 \%\end{array}$ & $0.00 \%$ & $\begin{array}{l}0.0 \\
0 \%\end{array}$ & $\begin{array}{l}0.0 \\
0 \%\end{array}$ & $\begin{array}{l}0.0 \\
0 \%\end{array}$ & $\begin{array}{l}0.0 \\
0 \%\end{array}$ \\
\hline UK 10-year Gilt & & $\begin{array}{c}94.63 \\
\%\end{array}$ & $\begin{array}{c}85 . \\
59 \\
\% \\
\end{array}$ & $\begin{array}{l}72 . \\
34 \\
\% \\
\end{array}$ & $\begin{array}{c}59 . \\
08 \\
\% \\
\end{array}$ & $\begin{array}{l}45 . \\
83 \\
\% \\
\end{array}$ & $32.58 \%$ & $\begin{array}{c}19 . \\
33 \\
\% \\
\end{array}$ & $\begin{array}{l}0.0 \\
0 \%\end{array}$ & $\begin{array}{l}0.0 \\
0 \%\end{array}$ & $\begin{array}{l}0.0 \\
0 \%\end{array}$ \\
\hline $\begin{array}{l}\text { Risk Premium on } \\
\text { Capital Allocation } \\
\text { Line }^{*}\end{array}$ & $\begin{array}{c}1.45 \\
\%\end{array}$ & $4.12 \%$ & $\begin{array}{l}4.5 \\
3 \%\end{array}$ & $\begin{array}{l}5.2 \\
8 \%\end{array}$ & $\begin{array}{l}6.0 \\
9 \%\end{array}$ & $\begin{array}{l}6.9 \\
3 \%\end{array}$ & $7.80 \%$ & $\begin{array}{l}8.6 \\
7 \%\end{array}$ & $\begin{array}{l}9.9 \\
7 \%\end{array}$ & $\begin{array}{c}11 . \\
65 \\
\%\end{array}$ & $\begin{array}{l}18 . \\
34 \\
\%\end{array}$ \\
\hline
\end{tabular}

*Risk premium on $\mathrm{CAL}=\mathrm{SD}$ * Sharpe Ratio

\begin{tabular}{|c|c|c|c|c|c|c|c|c|c|c|c|}
\hline & & $\begin{array}{c}\text { Min } \\
\text { Varian } \\
\text { ce }\end{array}$ & & & & & $\begin{array}{l}\text { Optim } \\
\text { um }\end{array}$ & & & & \\
\hline Mean & & $2.75 \%$ & $\begin{array}{l}3.5 \\
0 \%\end{array}$ & $\begin{array}{l}4.5 \\
0 \%\end{array}$ & $\begin{array}{l}5.5 \\
0 \%\end{array}$ & $\begin{array}{l}6.5 \\
0 \%\end{array}$ & $7.50 \%$ & $\begin{array}{l}8.5 \\
0 \%\end{array}$ & $\begin{array}{l}9.9 \\
7 \%\end{array}$ & $\begin{array}{l}10 . \\
50 \\
\%\end{array}$ & $\begin{array}{l}11 . \\
50 \\
\%\end{array}$ \\
\hline Standard Deviation & 0 & $0.71 \%$ & $\begin{array}{l}0.8 \\
2 \% \\
\end{array}$ & $\begin{array}{l}1.0 \\
2 \% \\
\end{array}$ & $\begin{array}{l}1.2 \\
3 \% \\
\end{array}$ & $\begin{array}{l}1.4 \\
6 \% \\
\end{array}$ & $1.69 \%$ & $\begin{array}{l}1.9 \\
2 \% \\
\end{array}$ & $\begin{array}{l}2.2 \\
6 \% \\
\end{array}$ & $\begin{array}{l}2.7 \\
1 \% \\
\end{array}$ & $\begin{array}{l}4.4 \\
8 \% \\
\end{array}$ \\
\hline Sharpe Ratio & & 1.84 & $\begin{array}{c}2.5 \\
1\end{array}$ & $\begin{array}{c}3.0 \\
0\end{array}$ & $\begin{array}{c}3.2 \\
9\end{array}$ & $\begin{array}{c}3.4 \\
7\end{array}$ & 3.59 & $\begin{array}{c}3.6 \\
8\end{array}$ & $\begin{array}{c}3.7 \\
7\end{array}$ & $\begin{array}{c}3.3 \\
4\end{array}$ & $\begin{array}{c}2.2 \\
4\end{array}$ \\
\hline All & & $0.00 \%$ & $\begin{array}{l}0.0 \\
0 \%\end{array}$ & $\begin{array}{l}0.0 \\
0 \% \\
\end{array}$ & $\begin{array}{l}0.0 \\
0 \% \\
\end{array}$ & $\begin{array}{l}0.0 \\
0 \%\end{array}$ & $0.00 \%$ & $\begin{array}{l}0.0 \\
0 \% \\
\end{array}$ & $\begin{array}{l}0.0 \\
0 \% \\
\end{array}$ & $\begin{array}{l}0.0 \\
0 \% \\
\end{array}$ & $\begin{array}{l}0.0 \\
0 \%\end{array}$ \\
\hline Retail & & $0.00 \%$ & $\begin{array}{l}0.0 \\
0 \%\end{array}$ & $\begin{array}{l}0.0 \\
0 \% \\
\end{array}$ & $\begin{array}{l}0.0 \\
0 \% \\
\end{array}$ & $\begin{array}{l}0.0 \\
0 \%\end{array}$ & $0.00 \%$ & $\begin{array}{l}0.0 \\
0 \% \\
\end{array}$ & $\begin{array}{l}0.0 \\
0 \% \\
\end{array}$ & $\begin{array}{l}0.0 \\
0 \% \\
\end{array}$ & $\begin{array}{l}0.0 \\
0 \%\end{array}$ \\
\hline Office & & $0.00 \%$ & $\begin{array}{l}0.0 \\
0 \%\end{array}$ & $\begin{array}{l}0.0 \\
0 \%\end{array}$ & $\begin{array}{l}0.0 \\
0 \%\end{array}$ & $\begin{array}{l}0.0 \\
0 \%\end{array}$ & $0.00 \%$ & $\begin{array}{l}0.0 \\
0 \%\end{array}$ & $\begin{array}{l}0.0 \\
0 \%\end{array}$ & $\begin{array}{l}0.0 \\
0 \%\end{array}$ & $\begin{array}{l}0.0 \\
0 \%\end{array}$ \\
\hline Industrial & & $5.37 \%$ & $\begin{array}{l}9.0 \\
5 \%\end{array}$ & $\begin{array}{l}10 . \\
81 \\
\%\end{array}$ & $\begin{array}{l}12 . \\
56 \\
\%\end{array}$ & $\begin{array}{l}14 . \\
31 \\
\%\end{array}$ & $16.06 \%$ & $\begin{array}{l}17 . \\
81 \\
\%\end{array}$ & $\begin{array}{l}20 . \\
82 \\
\%\end{array}$ & $\begin{array}{l}40 . \\
47 \\
\%\end{array}$ & $\begin{array}{l}77 . \\
59 \\
\%\end{array}$ \\
\hline Hotel & & $0.00 \%$ & $\begin{array}{l}0.0 \\
0 \% \\
\end{array}$ & $\begin{array}{l}0.0 \\
0 \% \\
\end{array}$ & $\begin{array}{l}0.0 \\
0 \% \\
\end{array}$ & $\begin{array}{l}0.0 \\
0 \% \\
\end{array}$ & $0.00 \%$ & $\begin{array}{l}0.0 \\
0 \% \\
\end{array}$ & $\begin{array}{l}0.0 \\
0 \% \\
\end{array}$ & $\begin{array}{l}0.0 \\
0 \% \\
\end{array}$ & $\begin{array}{l}0.0 \\
0 \% \\
\end{array}$ \\
\hline Residential & & $0.00 \%$ & $\begin{array}{l}4.7 \\
1 \%\end{array}$ & $\begin{array}{l}15 . \\
31 \\
\%\end{array}$ & $\begin{array}{l}25 . \\
90 \\
\%\end{array}$ & $\begin{array}{l}36 . \\
50 \\
\%\end{array}$ & $47.09 \%$ & $\begin{array}{l}57 . \\
69 \\
\%\end{array}$ & $\begin{array}{l}72 . \\
60 \\
\%\end{array}$ & $\begin{array}{l}48 . \\
93 \\
\%\end{array}$ & $\begin{array}{l}4.2 \\
0 \%\end{array}$ \\
\hline FTSE 100 Index & & $0.00 \%$ & $\begin{array}{l}0.6 \\
5 \%\end{array}$ & $\begin{array}{l}1.5 \\
5 \%\end{array}$ & $\begin{array}{l}2.4 \\
5 \%\end{array}$ & $\begin{array}{l}3.3 \\
6 \%\end{array}$ & $4.26 \%$ & $\begin{array}{l}5.1 \\
7 \%\end{array}$ & $\begin{array}{l}6.5 \\
8 \%\end{array}$ & $\begin{array}{l}10 . \\
61 \\
\%\end{array}$ & $\begin{array}{l}18 . \\
21 \\
\%\end{array}$ \\
\hline $\begin{array}{l}\text { FTSE EPRA Nareit } \\
\text { UK }\end{array}$ & & $0.00 \%$ & $\begin{array}{l}0.0 \\
0 \%\end{array}$ & $\begin{array}{l}0.0 \\
0 \%\end{array}$ & $\begin{array}{l}0.0 \\
0 \%\end{array}$ & $\begin{array}{l}0.0 \\
0 \%\end{array}$ & $0.00 \%$ & $\begin{array}{l}0.0 \\
0 \%\end{array}$ & $\begin{array}{l}0.0 \\
0 \%\end{array}$ & $\begin{array}{l}0.0 \\
0 \% \\
\end{array}$ & $\begin{array}{l}0.0 \\
0 \%\end{array}$ \\
\hline UK 10-year Gilt & & $\begin{array}{c}94.63 \\
\%\end{array}$ & $\begin{array}{l}85 . \\
59 \\
\%\end{array}$ & $\begin{array}{l}72 . \\
34 \\
\%\end{array}$ & $\begin{array}{l}59 . \\
08 \\
\%\end{array}$ & $\begin{array}{l}45 . \\
83 \\
\%\end{array}$ & $32.58 \%$ & $\begin{array}{l}19 . \\
33 \\
\%\end{array}$ & $\begin{array}{l}0.0 \\
0 \%\end{array}$ & $\begin{array}{l}0.0 \\
0 \%\end{array}$ & $\begin{array}{l}0.0 \\
0 \%\end{array}$ \\
\hline $\begin{array}{l}\text { Risk Premium on } \\
\text { Capital Allocation } \\
\text { Line* }\end{array}$ & $\begin{array}{c}1.45 \\
\%\end{array}$ & $4.12 \%$ & $\begin{array}{l}4.5 \\
3 \%\end{array}$ & $\begin{array}{l}5.2 \\
8 \%\end{array}$ & $\begin{array}{l}6.0 \\
9 \%\end{array}$ & $\begin{array}{l}6.9 \\
3 \%\end{array}$ & $7.80 \%$ & $\begin{array}{l}8.6 \\
7 \%\end{array}$ & $\begin{array}{l}9.9 \\
7 \%\end{array}$ & $\begin{array}{l}11 . \\
65 \\
\% \\
\end{array}$ & $\begin{array}{l}18 . \\
34 \\
\%\end{array}$ \\
\hline
\end{tabular}

${ }^{*}$ Risk premium on $\mathrm{CAL}=\mathrm{SD} *$ Sharpe Ratio

Source: Authors' compilation/analysis 
These calculations indicate residential property can contribute to a higher return/lower risk portfolio. Maybe not the lowest risk asset of the nine scrutinised but, where mean returns exceed $2.75 \%$, a percentage of capital should be allocated accordingly.

The minimum variance is when standard deviation is $0.71 \%$ and a Sharpe ratio of 1.82 . However, the optimum allocation of assets is when mean returns are $7.50 \%$, standard deviation is $1.69 \%$ and Sharpe ratio at 3.59. All ten scenarios are not hugely diversified insomuch as they include a maximum of four assets that offer the best average returns versus their standard deviations. A greater variety of assets would adversely affect the standard deviation level (risk) all other things remaining equal.

The Efficient Frontier, developed from Modern Portfolio Theory and Harry Markowitz (1952), is a valuable tool representing a series of optimal risk-return relationships and offers visualisation of diversification benefits of different assets. An Efficient Frontier was created containing all nine assets with the Risk Premium on Capital Allocation Line shown in red (Figure ). The Capital allocation Line demonstrates optimal returns when accounting for the risk free rate. Each dot marked on the graph represents the highest return for a given level of risk. The risk averse will typically target a point on the left of the graph (lower-risk, lower-return), while a more aggressive risk strategy will aim for the right side (higher return, higher risk). Any portfolio positioned below the efficient frontier is considered inefficient as the risks are not compensated with a higher return.

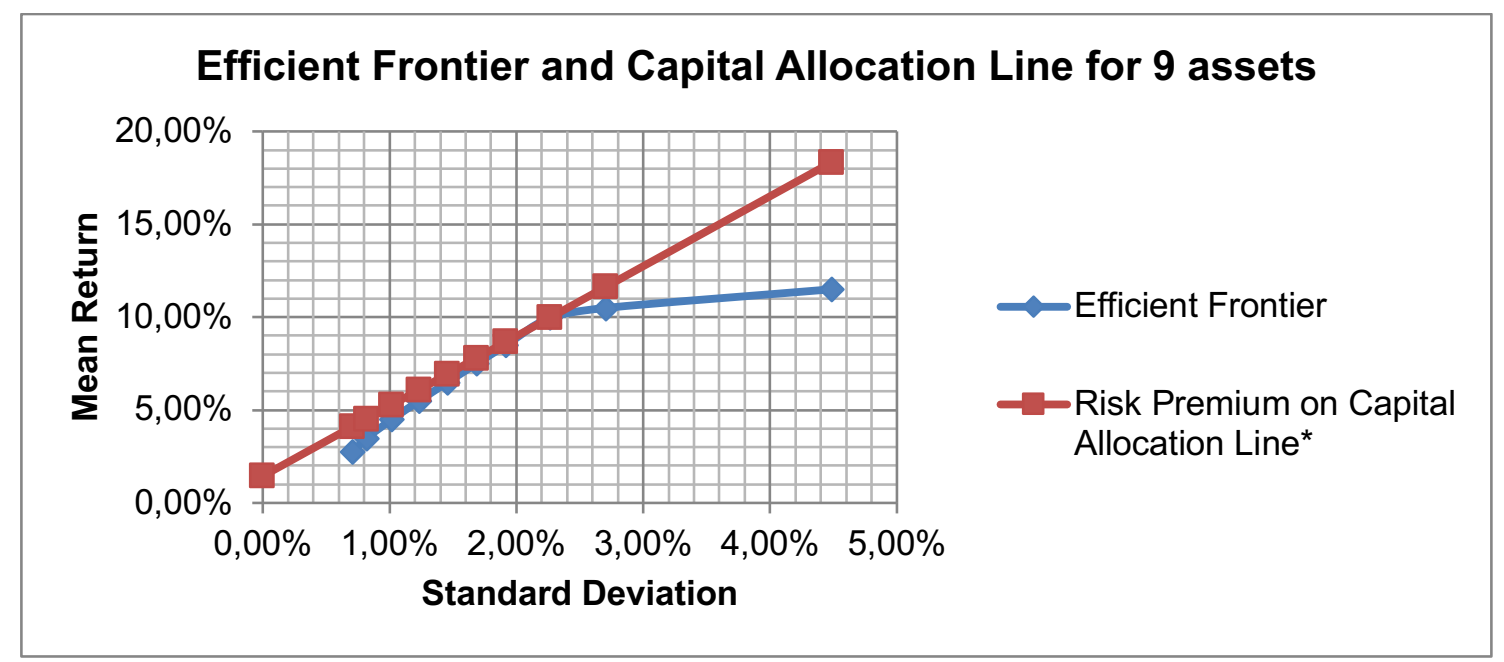

Figure 6 - Efficient Frontier and Capital Allocation Line for 9 assets

Source: Authors' compilation/analysis

Data analysis indicates the optimal portfolio allocation to residential property is $47.09 \%$. This point on the efficient frontier illustrates the optimal risk-return relationship above which, greater than $10 \%$ return, the level of expected risk increases substantially. Analysis was based upon 10 year averages which is considered indicative of risk-return.

Interestingly, within the optimal portfolio, only industrial property warrants inclusion. This demonstrates how sentiment towards property may shift towards lower-levered and lower-risk investments. BtR lends itself towards institutional investment and has potential to challenge, or even displace, the dominance retail and office demanded for so many years.

In summary, whilst past performance doesn't guarantee future performance, this quantitative analysis presents an argument for investing in UK BtR. The interviews provided a qualitative 
aspect of more subjective understanding of the position of BtR to reconcile with the quantitative research results.

Interview data examined property professionals' attitudes towards BtR. The somewhat volatile political climate at the moment prompted the interviews to span a two week period to minimise any impact externalities might otherwise have on the respondent's answers. Data has been grouped into 'themes' as per Braun and Clarke's (2006) model.

Risks of BtR

A number of risk factors and operational issues are associated with BtR accommodation. Interviewing a range of participants enabled the identification of those issues posing the greatest challenges. One recurring theme was occupancy and rental levels of BtR as the market expands and becomes more competitive. To minimise this developers will likely focus on high quality buildings that operate efficiently helping tenants feel valued and facilitating a sense of community, to reduce turnover rates. The BtR model currently targets the premium end of the market which, as levels of completed stock hit the market, may prove increasingly difficult to achieve. Therefore, there is scope for integrating a more diverse range of tenure types within future BtR developments; this may include affordable rents, premium rents and open market rents. Such a structure may negatively impact profits but simultaneously improve viability thresholds in certain locations.

Another key theme identified was the risk planning could have on BtR reaching its full potential. Two respondents viewed this a major obstacle for those on the 'front-line,' being involved in direct development and investment. To help ameliorate this, a shift is required from both central and local government to ensure more flexibility with section 106 agreements, Community Infrastructure Levy (CIL) and affordable housing contributions. These answers support the Montague Review findings (Montague , 2012).

The political argument was also raised by the same respondents. Perhaps there is bias here (depending where they sit on the political spectrum) as both expressed concern about a possible Labour government and the impact regulation and/or taxation change might have. This potential risk does however correspond with the report by Rob Thomas (2017). From an institutional perspective, it is difficult to diversify away domestically, but an international asset may be incorporated.

Finally, costs of delivering a high-end product capable of achieving premium rents and good occupancy rates could prove problematic according to respondents 4 and 5 . This has always been an issue for the PRS as identified by Mansfield (2000), so overcoming it is a fundamental challenge of the BtR sector. Keeping as many aspects of the process (including letting, property management and operations management) under one roof will help ensure costs and quality is monitored. Additionally, as portfolios grow, in-house economies of scale will minimise running costs. Respondent 5 refers to "long term upkeep of the building" which is still relatively unknown. Respondents $1 \& 5$ advised development costs for some BtR are higher than traditional build to sell, due to greater cost of more durable materials. For more forward-thinking developers, researching potential future cost reductions should be a priority.

\section{Allocation of BtR}

All respondents provided similar asset allocation levels, ranging between $25 \%-40 \%$, with respondent 4 refusing to commit to an exact figure. This range is unsurprising as it depends on the risk profile of the investor as to their chosen weighting towards BtR. This supports the empirical research findings which observed an allocation of between $25.90 \%$ and $47.09 \%$ (assuming a target return of between $5.50 \%-7.50 \%$ ). Conversely, the top end of the range (40\%) 
would occupy the full weighting of real estate within a portfolio as set out by Hoesli, et al. (2004). Nonetheless, consensus amongst the sample confirmed the reliability and stability of returns of BtR justifies inclusion within a portfolio. The exact weighting would be dictated by the investor's risk profile.

\section{Scaling up of BtR}

Questioning the 'scaling-up' potential of BtR, received a varied response. The appetite for 'second tier' markets such as Newcastle, Leeds, Bristol and Nottingham continues, with investors seeking to deploy capital in growing locations outside of core major cities. Four of the five interviewed, believe it is driven by lack of available sites in previously established centres (e.g. London and Manchester). This corresponds with the challenge identified by respondents 1 and 2, which is not only the availability of sites (due to planning constraints) but also affordability in both premium and secondary locations. Realistically, this can only be overcome by relaxation of planning laws, or developers purchasing at a higher price; the latter seems unlikely given their existing slim profit margins.

BtR is less established in large regional towns, but all agree towns with an established infrastructure, stable workforce, and strong education background, are suited to BtR. This has already commenced in towns like Crawley and Woking, with Surbiton mentioned as another potential location. Such secondary sites must be identified to future-proof the sector.

\section{$B t R$ a complimentary investment}

Growing popularity of BtR is well documented in the media and respondents agreed BtR is a positive investment option and a complimentary investment rather than substitute for CRE. The key driver is improved stability, albeit with lower returns than CRE. Respondents 5 and 4 provided greater detail regarding differing characteristics of BtR and CRE, supporting portolio inclusion of both. Due to the uncertain nature of the CRE market at present, Interviewee 1 indicated investors are interested in allocating a greater percentage of capital into BtR projects as opposed to CRE. As BtR evolves and CRE potentially deteriorates, BtR will likely play a greater role in institutional investment.

Next five years of BtR

Banks traditionally, only lent on permitted schemes. However, respondents 3 and 5 recognise the emergence of forward funding for BtR transactions proved attractive. Forward funding involves an initial payment to reimburse land cost, monthly instalments throughout construction and final payment upon completion. Lower profit margins are associated with BtR, but reduced selling expenses and interest costs can enhance profitability.

Supporting opinions within the literature review, all respondents agreed BtR will grow as an asset class over the next five years. The rate of growth will largely be dictated by the political and economic climate, which is likely shaped by Brexit (respondent 2). With growth, respondents 3 and 5 believe there will be increased competition looking for a 'slice of the pie'. This seems logical considering how rapidly student accommodation grew over the past 20 years. Consequently, respondents 1, 3, 4 and 5 believe developers will need to focus on first-class service and a customer focused offering. Nonetheless, developers need to control operational costs to remain affordable and financially viable.

\section{Research Limitations}

One of the shortcomings of this part of the study was the relatively small sample size of BtR developments available (25 out of 245). Although a large amount of data was analysed and 
influential individuals from across the industry interviewed, there is a paucity of detailed historical data regarding specific BtR developments. Developers seemed reluctant to share confidential data relating to capital and rental value growth, which is understandable particularly considering the infancy of the asset class. Although the sector has grown rapidly, obtaining enough historical data to accurately compare against other assets would be incredibly difficult and would compromise the investigation. As a result, residential indices were used as a foundation for analysis.

The main quantitative data was sourced from MSCI which, with the current existing BtR data provided the base to prove BtR a valuable and unique asset to reduce portfolio volatility and provide reliable long term investment income. These findings cannot be found in other academic literature.

As more developments are completed, there is opportunity for future research in the consolidated risk and return features of BtR in main cities and provincial centres. Of further interest would be the establishment of $\mathrm{BtR}$ as a major asset class within model investment portfolio construction.

Furthermore, portfolio composition is a broad subject and only eight major assets were compared against BtR. A more comprehensive study could consider a larger range of assets for comparison with the possible inclusion of commodities and cryptocurrencies.

\section{Summary, Conclusion and Recommendations}

The BtR construction pipeline is at 36,410, and a period of steady and sustained phase of growth is envisaged (BPF, 2019). The continuing success will depend on factors including taxation, investment and consumer appetite towards premium rental properties. Crucially, the UK Government must resist legislation and taxation with potentially inhibiting effects on future BtR investment. BtR can make a significant contribution towards UK's housing shortage but is reliant on continued support from an institutional perspective.

To conclude, research indicates BtR returns may not equate those of other assets, but it can provide lower risk, more stability and positive longer term investment benefits. Accordingly, it is anticipated an increased institutional participation in BtR accommodation will develop. With the rise of 'Generation Rent' and increased capital investment, BtR will likely migrate from 'alternative property' choice to a mainstream property sector within the next 10 years.

As the market matures and a longer timeframe of data emerges, further analysis can be completed. This should further validate robustness of strategic inclusion of UK BtR schemes in a mixed-asset portfolio. This research has shown BtR as an increasingly institutionalised asset and genuine alternative property sector for investors.

It is also vital for future research to assess the covariance of specific BtR schemes with other assets. However, as addressed already, BtR exhibits very similar characteristics to general residential property with added benefits of longer-tenancies and lower volatility. Accordingly, BtR developments can, and should, comprise a large proportion of residential property assets within a portfolio. The key will be affordability and supply constraints which may limit options available to institutional investors to include them, certainly in the short term. 


\section{References}

Alakeson, V. (2012). Making institutional investment in the private rented sector work. London: Resolution Foundation.

Amenc, N., Martellini, L., \& Ziemann, V. (2009). Inflation-Hedging Properties of Real Assets and Implications for Asset-Liability Management Decisions. The Journal of Portfolio Management, 35(4), 94-110. doi:https://doi.org/10.3905/JPM.2009.35.4.094

Baker, S., \& Edwards, R. (2012). How many qualitative interviews is enough? Southampton: National Center for Research Methods. Retrieved from http://eprints.ncrm.ac.uk/2273/.

Bank of England. (2018). Financial Stability Report: November 2018. Issue No. 44. London: Bank of England.

Bank of England. (2019). Official Bank Rate history. Retrieved July 10, 2019, from https://www.bankofengland.co.uk/boeapps/database/Bank-Rate.asp

Baum, A. (2009). Commercial Real Estate Investment: A Strategic Approach (2nd ed.). London: Estates Gazette Books.

Baum, A., \& Colley, N. (2017). Can Real Estate Investors Avoid Specific Risk. ABACUS, 53(3), 395430.

Belson, P. (2015). A task in hand. Land Journal, 8-9.

BPF. (2019). Build to Rent Q2 2019. London: BPF.

Braun, V., \& Clarke, V. (2006). Using thematic analysis in psychology. Qualitative Research in Psychology, 3(2), 77-101. Retrieved from http://dx.doi.org/10.1191/1478088706qp063oa

British Property Federation. (2013). Investing in residential property: A British Property Federation guide for asset allocation. London.

British Property Federation. (2017). Unlocking the Benefits and Potential of BTR.

British Property Federation. (2019, April 27). About the BPF. Retrieved from BPF.org.uk: https://www.bpf.org.uk/about-bpf

British Property Federation. (2019). Build to Rent Q1 2019. London. Retrieved June 12, 2019, from http://tiny.cc/baw57y

Byrne, P., \& Lee, S. (1995). Is there a place for property in the multi-asset portfolio? Journal of Property Finance, 6(3), 60-83.

Capital Value. (2018). An analysis of the Dutch residential (investment) market 2018. Retrieved June 15, 2019, from http://tiny.cc/f0hb8y

Cardoso, R., \& Meijers, E. (2017). Secondary Yet Metropolitan? The Challenges of Metropolitan Integration for Second-Tier Cities. Planning Theory \& Practice, 18(4), 616-635. doi:https://doi.org/10.1080/14649357.2017.1371789

Case, B., \& Wachter, S. (2011). Inflation and Real Estate Investments. 11-33.

CBRE. (2019). U.S. Real Estate Market Outlook.

Cheng, P., Lin, Z., Liu, Y., \& Zhang, Y. (2011). Has Real Estate Come of Age? Journal of Real Estate Portfolio Management, 17(3), 243-254.

Coghill, J., \& Hardman, J. (2015). Upfront: Valuing Build to Rent. Property Journal, May/Jun 2015, 9-11.

Collett, D., Lizieri, C., \& Ward, C. (2003). Timing and the Holding Periods of Institutional Real Estate. Real Estate Economics, 31(2), 205-222.

Colliers International. (2018, July 9). Colliers International's Build-to-Rent Rental Insights. Retrieved April 28, 2019, from Colliers International: https://urlzs.com/raqe

Cuddeback, G., Wilson, E., Orme, J., \& Combs-Orme, T. (2004). Detecting and Statistically Correcting Sample Selection Bias. Journal of Social Service Research, 30(3), 19-33. doi:10.1300/J079v30n03_02

Davies, B., Snelling, C., Turner, E., \& Marquardt, S. (2017). Lessons from Germany: Tenant power in the rental market. London: Institute for Public Policy Research. 
Davies, J. (2017). Looking to the future. Property Journal, 44-45.

EC Harris. (2013). Build to rent: Pushing the Boundaries. London: EC Harris. Retrieved from www.echarris.com

Eichholtz, P., Hoesli, M., Macgregor, B., \& Nanthakumaran, N. (1995). Real estate portfolio diversification by property type and region. Journal of Property Finance, 6(3), 39-59.

English Housing Survey. (2018). English Housing Survey- Headline Report, 2017-18. London: Ministry of Housing, Communities \& Local Government.

Eurostat. (2019). Distribution of population by tenure status, type of household and income group - EUSILC survey. Retrieved June 15, 2019, from http://appsso.eurostat.ec.europa.eu/nui/show.do?dataset=ilc_lvho02\&lang=en

Fisher, J., \& Sirmans, S. (1994). The Role of Commercial Real Estate in a Multi-Asset Portfolio. Journal of Property Management, 59(1), 54-55.

Fisher, M., \& Bloomfield, J. (2019). Understanding the research process. Journal of the Australasian Rehabilitation Nurses' Association (JARNA), 22(1), 22-27.

Guba, E., \& Lincoln, Y. (1994). Handbook of qualitative research (1 ed.). Thousand Oaks: Sage.

Hartzell, D., Hekman, J., \& Miles, M. (1986). Diversification Categories in Investment Real Estate. Journal of the American Real Estate and Urban Economics Association,, 14(2), 230-254.

Heaney, R., \& Sriananthakumar, S. (2012). Time-varying correlation between stock market returns and real estate returns. Journal of Empirical Finance, 19(4), 583-594.

HM Treasury. (2010). Government response to the consultation on investment in the private rented sector. London. Retrieved April 23, 2019, from https://urlzs.com/JhF1

HM Treasury. (2010). Investment in the UK private rented sector. London. Retrieved April 2, 2019, from https://urlzs.com/tkCo

Hoesli, M., \& MacGregor, B. (2000). Property investment: Principles and practice of portfolio management. Edinburgh: Pearson Education.

Hoesli, M., Bryan, M., Matysiak, G., \& Nanthakumaran, N. (1997). The Short-Term InflationHedging Characteristics of U.K. Real Estate. The Journal of Real Estate Finance and Economics, 15(1), 27-57.

Hoesli, M., Lekander, J., \& Witkiewicz, W. (2004). International Evidence on Real Estate as a Portfolio Diversifier. Journal of Real Estate Research, 26(2), 161-206.

Hoesli, M., Lizieri, C., \& MacGregor, B. (2008). The Inflation Hedging Characteristics of US and UK Investments: A Multi-Factor Error Correction Approach. The Journal of Real Estate Finance and Economics, 36(2), 183-206.

Hull, A., \& Cooke, G. (2012). Together at home: A new strategy for housing. Institute for Public Policy Research.

Huston, S., Rahimzad, R., \& Parsa, A. (2015). 'Smart' sustainable urban regeneration: Institutions, quality and financial innovation. Cities, 48, 66-75.

Hwang, S., Cho, Y., \& Shin, J. (2016). Does illiquidity matter in residential properties? Applied Economics, 49(1), 1-20.

Invesco. (2016). Whitepaper: UK Private Rented Residential Sector. London. Retrieved April 20, 2019, from http://tiny.cc/g0zg5y

Investing.com. (2019). FTSE 100 Total Return. Retrieved July 20, 2019, from https://uk.investing.com/indices/ftse-100-total-return-historical-data

Investing.com. (2019). FTSE EPRA/NAREIT UK Total Returns. Retrieved July 21, 2019, from https://uk.investing.com/indices/ftse-epra-nareit-uk-historical-data

IPD. (2014). The Asset Owner Real Estate Investment Process: Risk management insights from the MSCI/IPD survey. London: MSCI.

IPF. (2018). UK Residential Property: Institutional Attitudes and Investment Survey 2018. London: IPF Research Programme. 
Kallberg, J., Liu, C., \& Grieg, W. (1996). The Role of Real Estate in the Portfolio Allocation Process. Real Estate Economics, 24(3), 359-377.

Keeble, C., Law, G., Barber, S., \& Baxter, P. (2015). Choosing a Method to Reduce Selection Bias: A Tool for Researchers. Open Journal of Epidemiology, 5, 155-162. doi:http://dx.doi.org/10.4236/ojepi.2015.53020

Kivunja, C., \& Kuyini, A. (2017). Understanding and Applying Research Paradigms in Educational Contexts. International Journal of Higher Education, 6(5), 26-41.

Kuenzel, R., \& Bjørnbak, B. (2008). The UK Housing Market: Anatomy of a house. ECFIN Country Focus, 5(11), 1-10.

L\&G. (2019). Build to Rent: a new home for capital. London. Retrieved May 15th, 2019, from https://www.brighttalk.com/webcast/2163/355674/build-to-rent-a-new-home-for-capital

Lee, S., \& Stevenson, S. (2004). The Case for REITs in the Mixed-Asset Portfolio in the Short and Long Run. Journal of Real Estate Portfolio Management, 11(1), 55-80.

Lin, Z., \& Vandell, K. (2007). Illiquidity and Pricing Biases in the Real Estate Market. Real Estate Economics, 35(3), 291-330.

MacGregor, B., \& Nanthakumaran, N. (1992). The allocation to property in the multi-asset portfolio: The evidence and theory reconsidered. Journal of Property, 9(1), 5-32. Retrieved from https://doi.org/10.1080/09599919208724048

MacGregor, B., \& Nanthakumaran, N. (1992). The allocation to property in the multi-asset portfolio: The evidence and theory reconsidered. Journal of Property, 9(1), 5-32. Retrieved from https://doi.org/10.1080/09599919208724048

Mackenzie, N., \& Knipe, S. (2006). Research dilemmas: paradigms, methods and methodology. Issues In Educational Research, 16(2), 1-15.

Mansfield, J. (2000). Investment potential within the residential private rented sector. Property Management, 18(1), 34-45.

Mansley, N., \& Toplas, D. (2014). The inflation matching characteristics of mixed tenure private housing. London: Mill Group Ltd.

Markowitz, H. (1952). Portfolio Selection. The Journal of Finance, 7(1), 77-91.

Markowitz, H. (1952). Portfolio Selection. The Journal of Finance, 7(1), 77-91.

McIntosh, M., \& Morse, J. (2015). Situating and Constructing Diversity in Semi-Structured. Global Qualitative Nursing Research, 2, 1-12.

McKee, K., Moore, T., Soaita, A., \& Crawford, J. (2017). 'Generation Rent' and The Fallacy of Choice. Internation Journal of Urban and Regional Research, 41(2), 318-333.

McMillan, D. (2019). Cross-asset relations, correlations and economic implications. Global Finance Journal, 41, 60-78.

Miles, M., \& McCue, T. (1982). Historic Returns and Institutional Real Estate Portfolios. Real Estate Economics, 10(2), 184-199.

Montague, A. (2012). Review of the barriers to institutional investment in private rented homes. London: Department for Communities and Local Government.

Montezuma, J. (2006). A Survey of Institutional Investors' Attitudes and Perceptions of Residential Property: The Swiss, Dutch and Swedish Cases. Housing Studies, 21(6), 883908.

Moore, T. (2017). The convergence, divergence and changing geography of regulation in the UK's private rented sector. International Journal of Housing Policy, 17(3), 444-456.

MSCI. (2019). MSCI UK Monthly Property Index - May 2019. London: MSCI. Retrieved June 30, 2019, from https://www.msci.com/www/ipd-derivatives/derivative-ipd-ukmonthly/0164965629

MSCI. (2019). MSCI world index. Retrieved June 19, 2019, from https://www.msci.com/world

MSCI. (2019). UK Real Estate Quarterly Total Returns - 2009-2019. London: MSCI. 
Mueller, A., \& Mueller, G. (2003). Public and Private Real Estate in a Mixed-Asset Portfolio. Journal of Real Estate Portfolio Management, 9(3), 193-203.

Newman, I., Benz, C., \& Ridenour, C. (1999). Qualitative-Quantitative Research Methodology: Exploring the Interactive Continuum. Carbondale, IL: Southern Illinois University Press.

Office for National Statistics. (2018). Household projections in England: 2016-based. London: Ministry of Housing, Communities \& Local Government.

Office for National Statistics. (2019). House building; new build dwellings, England: December Quarter 2018. London: Ministry of Housing, Communities \& Local Government.

Office for National Statistics. (2019). UK private rented sector: 2018. London: ONS.

Old Mutual Wealth. (2019). Correlation Matrix for Asset Classes used with the Old Mutual Wealth Investment Tools. Retrieved June 19, 2019, from https://www.oldmutualwealth.co.uk/Adviser/investment-and-funds/investmentprocess/strategic-asset-allocation/process-and-assumptions/Correlation-matrix-forasset-classes-used-within-the-Old-Mutual-Wealth-investment-tools/

Pawson, H., \& Milligan, V. (2013). New dawn or chimera? Can institutional financing transform rental housing? International Journal of Housing Policy, 13(4), 335-357.

Pawson, H., \& Wilcox, S. (2013). UK Housing Review 2012/13. Coventry: Chartered Institute of Housing.

Pyhrr, S., Roulac, S., \& Born, W. (1999). Real Estate Cycles and Their Strategic Implications for Investors and Portfolio Managers in the Global Economy. Journal of Real Estate Research, 18(1), 7-68.

Rugg, J., \& Rhodes, D. (2018). The Evolving Private Rented Sector: Its Contribution and Potential. York: Centre for Housing Policy.

Savills. (2018). Investing in Private Rent. London. Retrieved April 3, 2019, from https://bit.ly/2Ue4nfR

Savills. (2019). Spotlight - Multifamily \& Co-living. London: Savills.

Savills. (2019). UK Build to Rent Market Update - January 2019. London.

Savills. (2019). UK Commercial Market in Minutes. London: Savills.

Scanlon, K., \& Wilson, J. (2017). Making the Most of Build to Rent. London: Future for London.

Scanlon, K., Fernández Arrigoitia, M., \& Whitehead, C. (2015). Social housing in Europe. European Policy Analysis, 17(1), 1-12.

Scanlon, K., Whitehead, C., Blanc, F., \& Moreno-Tabarez, U. (2017). The role of overseas investors in the London new-build residential market. LSE London.

Schulze, S. (2003). Views on the combination of quantitative and qualitative research approaches. Progressio, 25(2), 8-20.

Stephens, M., \& Williams, P. (2012). Tackling Housing Market Volatility in the UK: a Progress Report. York: Joseph Rowntree Foundation.

Thomas, R. (2017). Institutional investment in the private rented sector in the UK - coming of age. Housing Finance International, Winter 2017, 42-47.

United Nations. (2017). World Urbanization Prospects 2018. New York: United NationsDESA/Population Division.

Wilson, J., Russell, O., \& Scanlon, K. (2017). Making the most of build to rent. London, UK: LSE Consulting.

Wilson, W., \& Barton, C. (2019). What is affordable housing? London: The House of Commons Library . 
Appendix - Covariance Matrix

\begin{tabular}{|c|c|c|c|c|c|c|c|c|c|c|}
\hline $\begin{array}{l}\text { Portfolio } \\
\text { Weights }\end{array}$ & & $11.11 \%$ & $11.11 \%$ & $11.11 \%$ & $11.11 \%$ & $11.11 \%$ & $11.11 \%$ & $11.11 \%$ & $11.11 \%$ & $11.11 \%$ \\
\hline & & All & Retail & Office & Industrial & Hotel & Residential & $\begin{array}{c}\text { FTSE } \\
100 \\
\text { Index }\end{array}$ & $\begin{array}{c}\text { FTSE } \\
\text { EPRA } \\
\text { Nareit } \\
\text { UK }\end{array}$ & $\begin{array}{c}\text { UK 10- } \\
\text { year Gilt }\end{array}$ \\
\hline $11.11 \%$ & All & 0.0024 & 0.0023 & 0.0032 & 0.0022 & 0.0018 & 0.0007 & -0.0015 & 0.0017 & 0.0001 \\
\hline $11.11 \%$ & Retail & 0.0023 & 0.0027 & 0.0029 & 0.0012 & 0.0015 & 0.0009 & 0.0001 & 0.0024 & 0.0002 \\
\hline $11.11 \%$ & Office & 0.0032 & 0.0029 & 0.0047 & 0.0030 & 0.0025 & 0.0010 & -0.0030 & 0.0028 & 0.0001 \\
\hline $11.11 \%$ & Industrial & 0.0022 & 0.0012 & 0.0030 & 0.0043 & 0.0023 & 0.0000 & -0.0034 & 0.0001 & -0.0002 \\
\hline $11.11 \%$ & Hotel & 0.0018 & 0.0015 & 0.0025 & 0.0023 & 0.0018 & 0.0003 & -0.0013 & 0.0005 & 0.0000 \\
\hline $11.11 \%$ & $\begin{array}{l}\text { Residenti } \\
\text { al }\end{array}$ & 0.0007 & 0.0009 & 0.0010 & 0.0000 & 0.0003 & 0.0006 & 0.0005 & 0.0021 & 0.0001 \\
\hline $11.11 \%$ & $\begin{array}{l}\text { FTSE } 100 \\
\text { Index }\end{array}$ & -0.0015 & 0.0001 & -0.0030 & -0.0034 & -0.0013 & 0.0005 & 0.0117 & 0.0055 & 0.0004 \\
\hline $11.11 \%$ & $\begin{array}{l}\text { FTSE } \\
\text { EPRA } \\
\text { Nareit } \\
\text { UK }\end{array}$ & 0.0017 & 0.0024 & 0.0028 & 0.0001 & 0.0005 & 0.0021 & 0.0055 & 0.0197 & 0.0003 \\
\hline $11.11 \%$ & $\begin{array}{l}\text { UK 10- } \\
\text { year Gilt }\end{array}$ & 0.0001 & 0.0002 & 0.0001 & -0.0002 & 0.0000 & 0.0001 & 0.0004 & 0.0003 & 0.0001 \\
\hline $100.00 \%$ & & 0.0002 & 0.0002 & 0.0002 & 0.0001 & 0.0001 & 0.0001 & 0.0001 & 0.0004 & 0.0000 \\
\hline
\end{tabular}


Appendix BtR Sample Data

\begin{tabular}{|c|c|c|c|c|c|c|c|c|c|}
\hline Scheme No. & General Location & \multicolumn{2}{|c|}{ Transaction price } & \multicolumn{2}{|c|}{ Annual rent roll } & \multicolumn{2}{|c|}{ Rent psq pa. } & NIY & Transaction Date \\
\hline 1 & London & $£$ & $75,000,000$ & $£$ & $18,750,000$ & $£$ & 26.50 & $4.00 \%$ & 2018 \\
\hline 2 & London & $£$ & $96,000,000$ & $£$ & $24,242,424$ & $£$ & 27.00 & $3.96 \%$ & 2017 \\
\hline 3 & London & $£$ & $87,000,000$ & $£$ & $23,015,873$ & $£$ & 27.00 & $3.78 \%$ & 2017 \\
\hline 4 & London & $£$ & $64,000,000$ & $£$ & $16,842,105$ & $£$ & 27.00 & $3.80 \%$ & 2017 \\
\hline 5 & London & $£$ & $70,000,000$ & $£$ & $17,948,718$ & $£$ & 30.00 & $3.90 \%$ & 2019 \\
\hline 6 & London & $£$ & $42,000,000$ & $£$ & $10,769,231$ & $£$ & 31.00 & $3.90 \%$ & 2018 \\
\hline 7 & London & $£$ & $105,000,000$ & $£$ & $26,250,000$ & $£$ & 23.00 & $4.00 \%$ & 2019 \\
\hline 8 & London & $£$ & $67,000,000$ & $£$ & $16,750,000$ & $£$ & 27.00 & $4.00 \%$ & 2017 \\
\hline 9 & London & $£$ & $60,700,000$ & $£$ & $16,861,111$ & $£$ & 27.00 & $3.60 \%$ & 2015 \\
\hline 10 & London & $£$ & $104,000,000$ & $£$ & $29,131,653$ & $£$ & 30.00 & $3.57 \%$ & 2016 \\
\hline 11 & London & $£$ & $63,000,000$ & $£$ & $16,449,086$ & $£$ & 30.00 & $3.83 \%$ & 2016 \\
\hline 12 & London & $£$ & $75,500,000$ & $£$ & $23,593,750$ & $£$ & 32.00 & $3.20 \%$ & 2018 \\
\hline 13 & Manchester & $£$ & $45,000,000$ & $£$ & $1,720,000$ & $£$ & 31.00 & $3.82 \%$ & 2019 \\
\hline 14 & Liverpool & $£$ & $35,000,000$ & $£$ & $1,500,000$ & $£$ & 32.00 & $4.29 \%$ & 2019 \\
\hline 15 & London & $£$ & $59,000,000$ & $£$ & $2,250,000$ & $£$ & 30.00 & $3.81 \%$ & 2019 \\
\hline 16 & London & $£$ & $95,000,000$ & $£$ & $20,652,174$ & $£$ & 90.00 & $4.60 \%$ & 2018 \\
\hline 17 & London & $£$ & $8,400,000$ & $£$ & $2,270,270$ & $£$ & 32.00 & $3.70 \%$ & 2017 \\
\hline 18 & London & $£$ & $43,700,000$ & $£$ & $12,485,714$ & $£$ & 27.00 & $3.50 \%$ & 2017 \\
\hline 19 & London & $£$ & $23,700,000$ & $£$ & $6,771,429$ & $£$ & 31.00 & $3.50 \%$ & 2017 \\
\hline 20 & London & $E$ & $28,900,000$ & $E$ & $8,257,143$ & $£$ & 45.00 & $3.50 \%$ & 2017 \\
\hline 21 & London & $£$ & $91,000,000$ & $£$ & $36,400,000$ & $£$ & 27.00 & $2.50 \%$ & 2018 \\
\hline 22 & Bath & $E$ & $30,000,000$ & $E$ & $1,340,000$ & $£$ & 27.00 & $4.47 \%$ & 2019 \\
\hline 23 & Manchester & $E$ & $29,500,000$ & $£$ & $1,200,000$ & $E$ & 32.00 & $4.07 \%$ & 2019 \\
\hline 24 & South East & $£$ & $58,400,000$ & $£$ & $2,750,000$ & $E$ & 28.00 & $4.71 \%$ & 2019 \\
\hline 25 & London & $£$ & $73,600,000$ & $E$ & $3,150,000$ & $£$ & 27.00 & $4.28 \%$ & 2019 \\
\hline
\end{tabular}

